Chapman University

Chapman University Digital Commons

Economics Faculty Articles and Research

Economics

1967

\title{
Experimental Studies of Discrimination versus Competition in Sealed Bid Auction Markets
}

Vernon L. Smith

Chapman University, vsmith@chapman.edu

Follow this and additional works at: http://digitalcommons.chapman.edu/economics_articles

Part of the Economics Commons

\section{Recommended Citation}

Smith, Vernon L. "Experimental Studies of Discrimination versus Competition in Sealed Bid Auction Markets." Journal of Business, 40.1 (1967): 56-84.

This Article is brought to you for free and open access by the Economics at Chapman University Digital Commons. It has been accepted for inclusion in Economics Faculty Articles and Research by an authorized administrator of Chapman University Digital Commons. For more information, please contactlaughtin@chapman.edu. 


\section{Experimental Studies of Discrimination versus Competition in Sealed Bid}

Auction Markets

\section{Comments}

This article was originally published in Journal of Business, volume 40, issue 1, in 1967.

\section{Copyright}

University of Chicago 


\title{
EXPERIMENTAL STUDIES OF DISCRIMINATION VERSUS COMPETITION IN SEALED-BID AUCTION MARKETS*
}

\author{
VERNON L. SMITH†
}

\section{INTRODUCTION}

I $\mathrm{N}$ THIS study, attention focuses on the behavior of a class of auction markets where formal organization requires the individual competing bidders to submit one or more written "sealed bids" specifying the quantity and price at which they are committed to buy (or sell) units of the item being traded.

In many such markets only a single unit, such as a contract for the construction of a bridge or building, is involved. The experimental designs and theory underlying this study assume that many units of the item are to be offered for sale (or are required to be purchased). Perhaps the most important continuing market having this structure is the auction market for new Treasury bills with maturities of 91 and 182 days. Other examples might be the letting of contracts for transportation service, where the service requirements are in excess of the capacity of any single firm, or the letting of material contracts, say for cement, where the requirements exceed the capacity of any one producer.

Our primary purpose is to study individual bidding behavior and price determination under two alternative forms of market organization: (1) price discrimination, under which successful in-

\footnotetext{
* This research was supported by National Science Foundation Grant No. GS-370 to Purdue University. I wish to thank Mr. Meyer W. Belovicz for conducting one of the experimental sessions.

$\dagger$ Professor of economics and administrative science, Purdue University.
}

dividual bids are filled at their bid prices, and (2) pure competition, under which successful individual bids are filled at the same market-clearing price. The methodology is that of the controlled laboratory experiment, in which the major "treatment" variables are the instructions defining the rules for accepting subject bids under the two forms of market organization.

\section{INSTITUTIONAL EXAMPLES: THE TREASURY-BILL AUCTION}

For institutional background we discuss briefly some mechanics of the Treasury-bill auction. This auction is an ideal example because its organization and functioning are known in considerable detail, and it has been proposed that the discriminative practice of the Treasury be replaced by a competitive procedure. ${ }^{1}$ However, the bill auction,

${ }^{1}$ Andrew Brimmer, "Price Determination in the United States Treasury Bill Market," Review of Economics and Statistics, XLIV, No. 2 (May, 1962), 178-83; Deane Carson, "Treasury Open Market Operations," Review of Economics and Statistics, Vol. XLI, No. 4 (November, 1959); Henry Goldstein, "The Friedman Proposal for Auctioning Treasury Bills," Journal of Political Economy, LXX, No. 4 (August, 1962), 386-92; Joint Economic Committee, Congress of the United States, "Constructive Suggestions for Reconciling and Simultaneously Obtaining the Three Objectives of Maximum Employment, and Adequate Rate of Growth, and Substantial Stability of the Price Level," Hearings: Employment, Growoth and Price Levels (86th Cong., 1st sess., October, 1959), Part 9A, pp. 3023-26; Milton Friedman, A Program for Monetary Stability (New York: Fordham University Press, 1960), pp. 63-65; and Michael Rieber, "Collusion in the Auction Market for Treasury Bills," Journal of Political Economy, LXXII, No. 5 (October, 1964), 509-12. 
as such, has no dominating interest for this study. Our interest is in the general characteristics of the sealed-bid auction and the effect of price discrimination and pure competition on behavior, whether the commodity be securities or potatoes.

The bill auction is a weekly phenomenon beginning each Wednesday when the Treasury releases an announcement, through the Reserve Banks, inviting tenders for a specified amount of 91-day and 182-day issues. The weekly offering of 91-day issues amounts to around one billion dollars, that of the longer issue about half a billion. The resulting bids are normally tendered the following Monday to each Reserve Bank by the bill investors in each Federal Reserve district. Delivery is made to the successful bidders on the following Thursday. Before 1947, all bids had to be entered at a specified price. Since 1947, investors have had the option of submitting noncompetitive bids for limited amounts of bills. The successful competitive bids are filled at their individual-bid prices, while the non-competitive bids are filled at a quantity-weighted average of the accepted competitive bids. (Incidentally, "competitive" as used in the Treasuryauction literature does not mean "competitive" as we shall employ the term in contrast to the term "discriminative.")

To illustrate price determination, suppose that the net offering of ninety-oneday bills to the competitive bidders is $Q_{0}$ in Figure 1. $Q_{0}$ would be the total offering minus the amount of non-competitive bids. The array of competitive bids from highest to lowest forms an effective demand, $d d$, for the offering. The lowest accepted bid would be at $P_{L}$, the highest at $P_{H}$.

In this illustration, the gross receipts from the offering are given by the area under $d d$ and to the left of $Q_{o}$ in Figure
1. Thus, with respect to the effective demand curve, $d d$, the seller acts as a perfect price discriminator, receiving all the buyer's rent or surplus under the demand curve. By contrast, if this market were operated to simulate a perfectly competitive auction, and if we assume the same bids to have been submitted as in the example for price discrimination, the result would have been the uniform market-clearing price, $P_{L}$, for

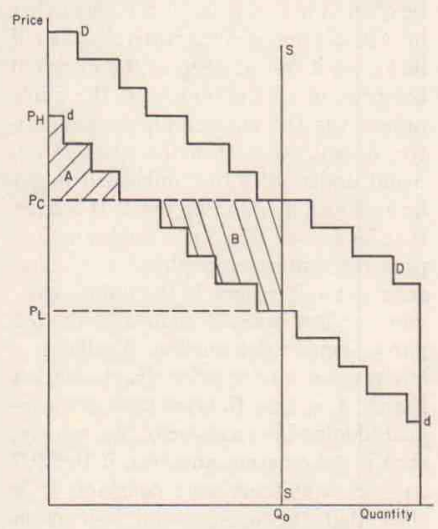

Fig. 1.-Price determination in the bill auction

all successful bidders. Under these assumptions, the Treasury receives greater revenue as a consequence of practicing price discrimination. However, as is demonstrated in the bidding theory outlined in Appendix I, it is not necessarily the case that the bids will be the same under price discrimination as under a purely competitive market organization. ${ }^{2}$

For illustration, suppose each bidder, $i$, in the market has a firm reservation price, $P_{i}$, that he is willing to pay for a unit of the item traded. Then the "po-

2Also cf. Goldstein, op. cit., pp. 391-92. 
tential" demand, or limit-price set, is determined by the ordered set $\left[P_{i}\right]$ arrayed in descending order from highest to lowest. Such a set is illustrated by $D D$ in Figure 1 and corresponds to the demand curve of ordinary price theory. As is shown in Appendix I, under price discrimination the optimal-price bid for any buyer is not in general equal to his reservation limit, $P_{i}$. Intuitively, when a buyer knows that a successful bid will be filled at his bid price, it is evident that he will bid more conservatively than if he knows it will be filled at the marginal bid price of all the buyers. If the limitprice set is $D D$ under a purely competitive organization, then the effective demand under price discrimination might be as shown by $d d$ in Figure 1. It follows that for a given $D D$, and a single auction, price discrimination might yield a seller, such as the Treasury in the bill auction, more or less revenue than a simulated purely competitive auction. A seller gets less revenue under price discrimination if area $A<$ area $B$. Over time, with repeat bidding in successive (daily, weekly, etc.) discrimination auctions, if the $D D$ and $S S$ conditions were constant, it is clear that the unsuccessful bidders in earlier auctions would tend to raise their bids, while the successful bidders would tend to lower their bids. Consequently, area $B$ would approach zero, as $d d$ (to the right of $S S$ ) rose toward $D D$. But in any real market, and most certainly in the bill auction, both $D D$ and $S S$ change from one auction to another. Hence the price uncertainties which lead one to expect $d d$ to be below $D D$ may persist indefinitely over time. ${ }^{3}$ An important objective of our experimental design will be to capture the essence of this uncertainty in a laboratory setting.

The above considerations arise in an auction conducted by a single buyer, except that in this case the demand curve is vertical at the desired quantity and the purely competitive supply curve is formed from the ordered set of offerlimit prices. Under discrimination the supply-price bids would tend to exceed the limit-supply prices. The effective supply function would therefore be to the left of that prevailing in a competitive auction. If the difference were sufficiently great a buyer might pay more for the purchase under discrimination than in a competitive auction.

\section{THE EXPERTMENTAL PARADIGM}

In designing an experimental paradigm for the study of behavior in the sealed-bid auction market it will not be our objective, even if it were possible, to simulate the institutional details of any particular market such as the Treasury-bill auction. We shall be concerned, rather, with creating a group task situation that reflects the essential economic characteristics of such a market. These characteristics seem to be three in number:

1. The individual participants in such a market can be expected to place (a) different and $(b)$ uncertain subjective valuations on the commodity being exchanged.

2. The price at which units of the commodity can be purchased in the auction cannot be known with certainty at the time the participants tender their irrevocable bids.

3. The rules for determining who pays how much for the commodity might be either of the discriminative form or the purely competitive form.

These characteristics are incorporated into the experimental design by requiring

s There is even uncertainty as to SS in the bill auction since the Treasury announcement always invites tenders for $\$ X$ billion, or thereabouts. The Treasury is thereby in a position to cut the bid array with its own reservation sale price if the bids are unusually thin or thick. In practice, there seems to be negligible deviation between the announced offering and the actual volume of bids accepted. 
the subjects to submit irrevocable bids for units of an abstract commodity, offered inelastically in specified quantity, for resale at a price that is a random variable with a specified mass or frequency function. The subjects are paid in U.S. currency a sum equal to the algebraic difference between selling price and purchase price. Since the subjects may be presumed to have different subjective valuations (utility functions) for money, this paradigm satisfies condition $1(a)$. Condition $1(b)$ is satisfied by making resale price a random variable. The fact that it is a known random variable corresponds roughly in a real market to the knowledge and judgmental ability that the participants gain from experience. Condition 2 is satisfied by prohibiting communication among the subjects. Hence, no individual subject can have certain knowledge, in advance, of purchase price or selling price. Of course Condition 3 is satisfied by varying the bidding rules as between two experimental groups.

In the Treasury-bill market this experimental paradigm corresponds most directly to the dealer participants who buy in the primary auction for purposes of resale in the secondary, existing-asset market. Dealer profits are squeezed from below by uncertainty as to the lowest accepted bid that will prevail in the Treasury auction and from above by uncertainty as to the price at which they can resell the bills in the existing-asset market. The assumption that "resale price" is uncertain may also correspond indirectly to the behavior of some non-dealer bidders in the Treasury auction. Thus, although a participant may not be buying for resale, he may still be influenced, in placing his bids, by his estimate of the expected future price of bills in the secondary market at the time of delivery of new bills acquired in the auction. If he wishes to minimize his opportunity cost of buying in the primary market, when he might have bought in the secondary at a more favorable price, such behavior would be formally equivalent to that of a dealer bidding to maximize some utility function of profit.

\section{THE HYPOTHESES}

Prior to conducting the experiments reported in this paper several specific hypotheses were formulated, which helped to govern the experimental design. In each case we will state the research hypothesis, it being understood that the classical null alternative is the negative of the research hypothesis. The use of a $C$ will refer to "competitive treatment," a $D$ to "discriminative treatment."

The basic hypothesis, labeled $\mathrm{H}_{2}$, grows directly out of the intuitive arguments in the previous section and the bidding theory in Appendix I:

$\mathrm{H}_{g}$ : In the th auction period, the bids, $B_{C}^{t}$, tendered by subjects in a $C$ group will exceed ${ }^{4}$ the bids, $B_{D}^{t}$, tendered by subjects in the corresponding $D$ group, that is, $B_{c}^{t}>B_{D}^{t}, t=1,2$, $3, \ldots$

When we come to test $\mathrm{H}_{2}$ it will be necessary to select a test procedure. The obvious classical test is a simple onetailed $t$ test on the means of the bids. However, the $t$-test requires the assumption that the two samples being compared are from populations with the same variance. Therefore, before $\mathrm{H}_{2}$ can be tested, it is necessary to formulate a hypothesis as to the behavior of the variance of bids tendered under the two

"The precise meaning of "exceed" is defined implicitly by the bid-test statistic used in the comparison. The use of a $l$-test would imply that the mean $B_{c}^{t}$ and $B_{b}^{t}$ would satisty the inequality $B_{c}^{t}>B_{D}^{t}$. The use of a rank-order non-parametric test would imply that the sum, mean, or other function of the ranks assigned to bids satisfied the hypothesized inequality. 
treatments. Such a hypothesis will be of intrinsic interest in that, if true, it will reflect a behavioral difference caused by the different treatments. What in fact can we expect? Will the variance of the bids under condition $C$ be greater, equal, or less than the variance of the bids under condition $D$ ? The following argument suggests that the variance will be greater:

The individual bidder in a discriminative auction is uncertain as to whether a given bid will be successful, but if it is successful he is certain about the purchase price-his purchase price, by defi- ward risk vary among individual subjects, some will "gamble" with high bids, others will play it safe with more conservative bids. Hence, the variance of bids under $C$ should exceed that of bids under $D$.

$\mathrm{H}_{1}$ : In the th auction period, the variance of bids tendered by subjects in a $C$ group, $V\left(B_{C}^{t}\right)$, will exceed the variance of bids tendered by subjects in the corresponding $D$ group, $V\left(B_{D}^{t}\right)$, that is, $V\left(B_{C}^{t}\right)>V\left(B_{D}^{t}\right), t=1,2,3, \ldots$

It is instructive to consider the rationale for $\mathrm{H}_{1}$ and $\mathrm{H}_{2}$ from the point of view of a game matrix. Consider the following highly simplified illustration: Suppose an

TABLE 1

SUBJECT'S PAYOFF

\begin{tabular}{|c|c|c|c|c|c|c|}
\hline \multirow{3}{*}{$\begin{array}{c}\text { Ir Sunject } \\
\text { Bubs }\end{array}$} & \multirow{2}{*}{\multicolumn{3}{|c|}{$\begin{array}{l}\text { Hypotartical } D \text { Payomy Matzex } \\
\text { If Others Bid (or the Low Bid Is): }\end{array}$}} & \multirow{2}{*}{\multicolumn{3}{|c|}{$\begin{array}{l}\text { Hypothetical C Payomy Materx } \\
\text { If Others Bid (or the Low Bid Is): }\end{array}$}} \\
\hline & & & & & & \\
\hline & 1 & 2 & 3 & 1 & 2 & 3 \\
\hline$\frac{1}{2}, \ldots \ldots \ldots \ldots$ & $\begin{array}{r}\frac{1}{3} \\
0 \\
-1\end{array}$ & $\begin{array}{r}0 \\
0 \\
-1\end{array}$ & $\begin{array}{r}0 \\
0 \\
-\frac{1}{2}\end{array}$ & $\begin{array}{l}\frac{1}{2} \\
\frac{1}{1} \\
1\end{array}$ & $\begin{array}{l}0 \\
0 \\
0\end{array}$ & $\begin{array}{r}0 \\
0 \\
-\frac{1}{2}\end{array}$ \\
\hline
\end{tabular}

nition, will be his bid price. He has little incentive to bid "high," for although it will increase the certainty that a bid will be accepted it raises his purchase price and lowers his profit. But in a competitive auction the individual bidder faces uncertainty both as to whether a given bid will be accepted and as to what his purchase price will be. If he bids high this increases his chance of success, and, provided that others bid low, his purchase price is low, and he makes a profit. The individual is not penalized no matter how much his bid exceeds the lowest accepted bid. But if others bid high it raises the purchase price to all, and all suffer losses. This implies greater risk under condition $C$, and, if attitudes to- individual subject can enter one of three bids, 1,2 , or 3 , and that resale price is 1,2 , or 3 , with equal probability. Also assume that when a subject ties with others for low bids he has a $\frac{1}{2}$ chance of having his bid accepted. Now imagine that a typical subject is concerned with what he should bid on the assumption that others bid (or the low bid is) a 1, 2, or 3 . Under the $D$ or $C$ conditions our subject might perceive the payoffs given in Table 1.

In $D$, if he bids 1 and others bid 1 , his bid is accepted $\frac{1}{2}$ the time, giving a profit of 0,1 , or 2 with chances $\frac{1}{3}$ each. Hence, payoff averages $\frac{1}{2}$. If he bids 1 and others a 2 or 3 , he gets nothing. If he bids 2 and others 1 , his bid is accepted 
but at an average profit of 0 . If he bids 2 and others 2 he still averages 0 , while if others bid 3 his bid is never accepted, giving 0 , and so on. In $D$ it is best to go low, while a high bid never pays. Some might try bids of 2 since it still involves fair odds, and one could "get lucky." Hence, bids of 1 are most likely, with perhaps a few at the resale mean, 2 . Note that a bid of 1 is both the co-operative (joint maximizing) and the selfish course of action.

The same payoff vector accrues in $C$ for a bid of 1 . If our hypothetical subject bids 2 and others 1 , his bid is always accepted and filled at 1 , the lowest accepted bid, giving an average profit of $1\left(=\frac{1}{3} \cdot 0+\frac{1}{3} \cdot 1+\frac{1}{3} \cdot 2\right)$. If he bids 2 and others 2 , he averages 0 , and so on. In $C$ it is best to bid 2. However, if a subject is anxious to co-operate he might bid 1 , which cannot generate a loss. If he hopes to intimidate others into making low bids he will bid rivalistically at 3 , risking a loss of $\frac{1}{2}$ but also inflicting a loss of $\frac{1}{2}$ on all others who bid 3 . The "right" course of action is less evident in $C$ than in $D$.

From this example it is clear that the bids would tend to be higher in $C$ than in $D\left(\mathrm{H}_{2}\right)$. Given that subject attitudes toward risk and toward punishing versus co-operative strategies are likely to vary, it is seen that the $C$ bids would tend to have a higher variance than $D$ bids $\left(\mathrm{H}_{1}\right)$.

Given the validity of $\mathrm{H}_{2}$, it is conjectural whether the bids will be high enough in the $C$ group to yield a monopolistic seller greater revenue under competition than discrimination. This prospect was considered sufficiently likely to assert the following hypothesis:

$\mathrm{H}_{3}$ : In the $t$ th auction period the total revenue to a seller in a $C$ group, $R_{C}^{t}$, will exceed that in the corresponding $D$ group, $R_{D}^{t}$, that is, $R_{C}^{t}>R_{D}^{t}, t=1,2,3, \ldots$
Although the classical experimental methodology calls for independent subject groups to be exposed to the treatment conditions whose effects are to be compared, there is an important sense in which such a procedure is artificial in the present context. In any actual institutional form of the sealed-bid auction, such as the Treasury-bill auction, the participants have a long-standing experience with the discriminative form of organization. If market organization is changed to the competitive form, will the previous history and experience have an important effect on behavior under the new conditions? If one is concerned with the Carson-Friedman policy proposal, namely, to change from discriminative rules to competitive rules, ${ }^{5}$ then the relevant experiment is to expose the same group of subjects initially to the discriminative treatment for a series of bid periods, then to the competitive treatment. Although some "hystereses" (or path-dependent) phenomena may be detectable, it is expected that the above propositions will be valid when the same experimental group is exposed first to the $D$, then to the $C$, conditions. The above three hypotheses will be labeled $\mathrm{H}_{1}^{\prime}, \mathrm{H}_{2}^{\prime}$, and $\mathrm{H}_{3}^{\prime}$ when applied to comparable bid periods under the $D$ and $C$ conditions for the same experimental group.

Although we are prepared to predict that the bids will be lower and the seller's receipts lower under discrimination, it is apparent that such results are not likely to be independent of market conditions, in particular the relative number of rejected bids. Ceteris paribus, it would appear that the greater the volume of rejected bids the higher would tend to be the bids under either the $C$ or $D$ condi-

\footnotetext{
${ }^{5}$ Carson, op. cit.; Joint Economic Committee, op. cit.
} 
tion. However, since we expect the bids to be higher, and therefore the trading gains thinner, under $C$ (as opposed to $D$ ), we will expect the volume of excess bids to have its most pronounced effect under condition $D$. Indeed, at some point, as the number of bidders is increased in successive experimental groups, with the offering quantity constant, the differential effect of the $C$ and $D$ conditions on seller revenue may disappear. These expectations will be tested via hypotheses $\mathrm{H}_{4}$ and $\mathrm{H}_{5}$.
The instruction sheets given each subject in the $D$ experiments, and read aloud to the entire group, are reproduced in Appendix II. Appendix II also contains the $C$ instructions.

Group III participated in two experiments conducted in sequence. In the first experiment (IIID), the $D$ instructions were read, followed by a trial auction, then by eight auctions for money. Then without advance warning the $C$ instructions were read followed by eight more auctions (experiment IIIC). The

TABLE 2

EXPERIMENTAL-DESIGN CONDITIONS

\begin{tabular}{|c|c|c|c|c|}
\hline Experiment & $\begin{array}{l}\text { Purchase- } \\
\text { Price Rules }\end{array}$ & $\begin{array}{l}\text { No. of } \\
\text { Subjects }\end{array}$ & $\begin{array}{l}\text { No. of Re- } \\
\text { jected Bids }\end{array}$ & $\begin{array}{l}\text { No, of Bid } \\
\text { Periods }\end{array}$ \\
\hline $\begin{array}{l}\mathrm{I} D \ldots \ldots \ldots \\
\operatorname{II} C \ldots \ldots \\
\operatorname{III} D \ldots \ldots \\
\operatorname{III} C \ldots \ldots \\
\operatorname{IV} D \ldots \ldots \\
\text { VC } \ldots \ldots .\end{array}$ & $\begin{array}{l}\text { Discriminative } \\
\text { Competitive } \\
\text { Discriminative } \\
\text { Competitive } \\
\text { Discriminative } \\
\text { Competitive }\end{array}$ & $\begin{array}{l}15 \\
15 \\
13 \\
17 \\
17\end{array}$ & $\left\{\begin{array}{r}12 \\
12 \\
8 \\
8 \\
16 \\
16\end{array}\right.$ & $\left\{\begin{array}{r}5 \\
5 \\
8 \\
8 \\
10 \\
10\end{array}\right.$ \\
\hline
\end{tabular}

$\mathrm{H}_{4}$ : With a fixed offer quantity, in corresponding auction periods, bids tendered by subjects in $D$ groups, $B_{D}^{t}$, will be higher the greater the number of rejected bids, that is, $B_{D}^{t}\left(N R_{1}\right)>$ $B_{D}^{t}\left(N R_{2}\right)>B_{D}^{t}\left(N R_{3}\right)>\ldots, t=1,2,3, \ldots$, if $N R_{1}>N R_{2}>\mathrm{NR}_{3}>\ldots$

$\mathrm{H}_{5}$ : Same as $\mathrm{H}_{4}$ applied to $C$ groups, that is, $B_{C}^{t}\left(N R_{1}\right)>B_{C}^{t}\left(N R_{2}\right)>B_{C}^{t}\left(N R_{3}\right)>\ldots$, $t=1,2,3, \ldots$, if $N R_{1}>N R_{2}>N R_{3}>\ldots$

\section{EXPERIMENTAL DESIGN}

A total of seventy-seven subjects, all in undergraduate courses in economics and industrial management at Purdue, participated in a design block of six experiments conducted in five groups or sessions. No subject participated in more than one session. The relevant experimental conditions for each session are designated in Table 2. Roman numerals I through $\mathrm{V}$ refer to the five subject groups in the chronological order in which the experiments were conducted. other four experiments were conducted on independent groups of subjects.

Group III consisted of an entire student class, whereas the other groups were randomized out of much larger classes. As a means of controlling on pregame conditions the classes were given no advance warning that they would serve as captive subjects in an experiment. End effects were controlled by withholding information on the number of auction periods.

As indicated in the instructions, in each experiment the number of bids that could be submitted by a subject was arbitrarily set at two. The quantity offered, $X$, was announced at the beginning of each auction period. This offering was eighteen units in all periods of all experiments, but the subjects discovered this only through the sequential announcements. Hence, in experiments $I D$ 
and IIC, a total of thirty bids (fifteen subjects) was submitted of which twelve were rejected. Similarly in IIID and IIIC eight bids were rejected out of twenty-six, and in IVD and VC we have sixteen bids rejected out of thirty-four.

In each auction of each experiment a subject's profit on a successful bid was (selling price) - (purchase price), zero otherwise, this sum to be added to or subtracted from his $\$ 1.00$ starting capital. In both the $D$ and $C$ auctions the lowest successful bid was determined by arraying the bids from highest to lowest and accepting the first $X$ bids. In the $C$ auctions "purchase price" was determined by the lowest successful market bid, while in the $D$ auctions it was determined by the bid price on each individual accepted bid. In both auctions

TABLE 3

BID FREQUENCIES BY AUCTION PERIOD ${ }^{a}$

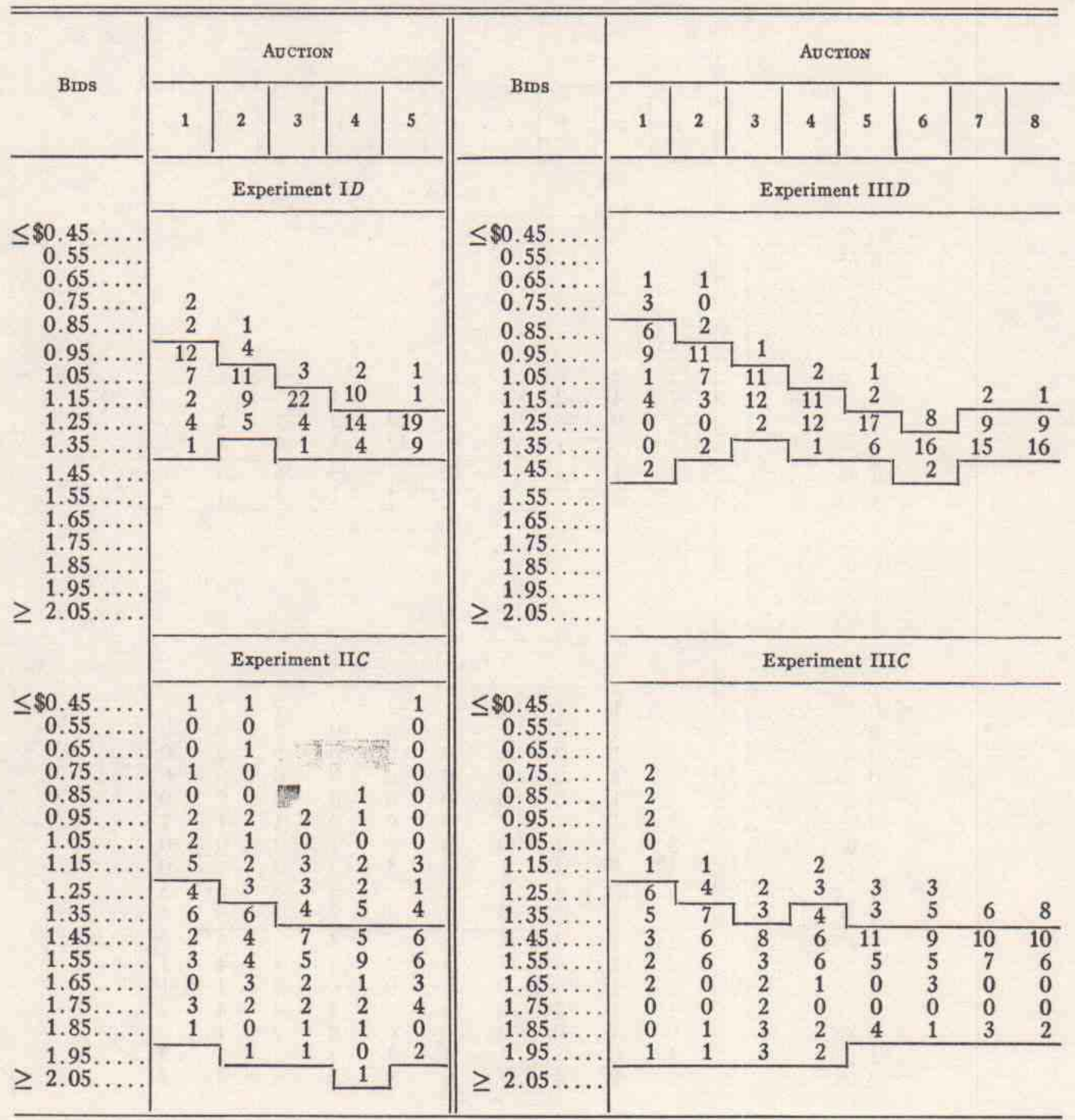

- Bids between the rules = accepted bid range. 
"selling price" was determined by independent drawings from a rectangular distribution over the nine prices, $\$ 1.15$, $\$ 1.25, \$ 1.35, \ldots, \$ 1.95$. Each auction began with an announcement that eighteen units were being offered for sale and ended with an announcement of the highest accepted bid, the lowest accepted bid, and the result of the drawing to determine "resale price." All data were written on the blackboard at the time of announcement and left there in tabular form for the duration of the experiment.

Each session began with a trial auction which did not count toward the computation of the subject's cash rewards. Following the trial auction further questions concerning the mechanics of the auction were invited. The same

TABLE 4

BID Frequenctes by AuCtion PERIODa

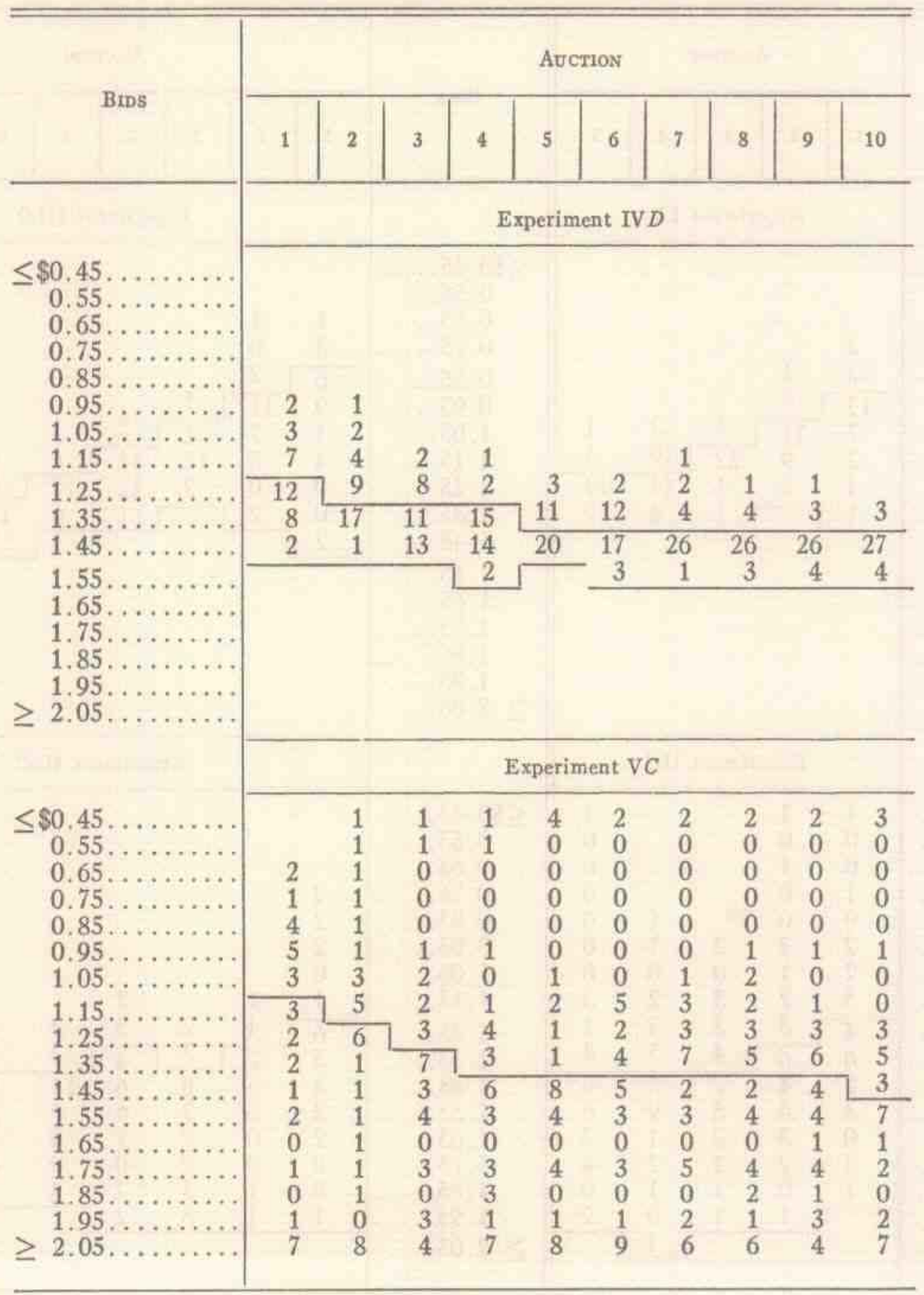

- Bids between rules $=$ accepted bid range. 
random sequence of resale prices was used in all experiments (except $\mathrm{III} D$, since it was the same subject group as IIIC) as a control on the effect of particular sequences.

\section{RESULTS, TESTS OF HYPOTHESES}

The data to be analyzed from the five experiments are compiled in Tables 3 and 4. Complete protocols of bids by individual subjects are reported in Appendix III. Tables 3 and 4 contain the frequency of each bid tendered in each auction period. The highest and lowest of the accepted bids, by auction period, are indicated by the rules. Except for ties at the low-bid price which were randomly assigned to the acceptance and

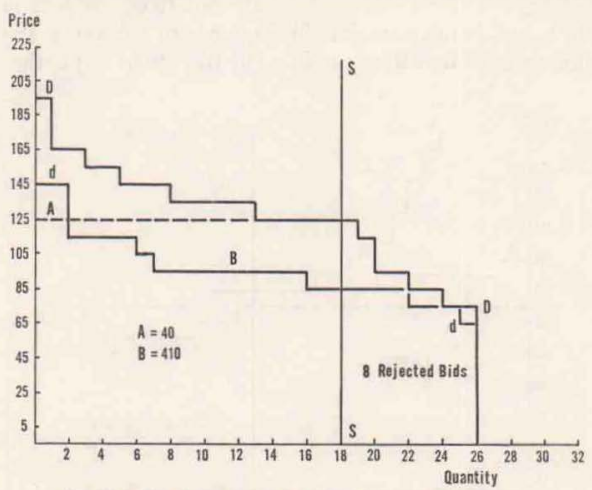

FIG. 2.-Experiments $I I D$ and $I I C$, auction period 1

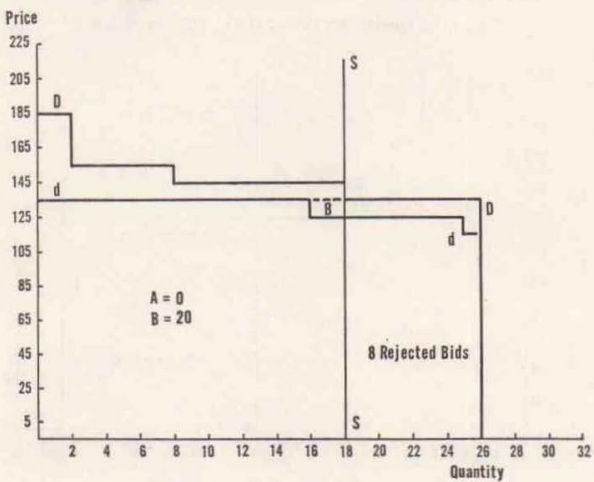

FrG. 3.-Experiments $I I D$ and $I I I C$, auction period 8 
rejection sets, the bids between these rules constitute the acceptance set of bids. For example, in auction period 3 , experiment IIC, eighteen bids were between $\$ 1.45$ and $\$ 1.95$, and therefore all were accepted. In auction 4 of the same experiment, nineteen bids fell in the $\$ 1.45-\$ 2.05$ range. Hence, one of the $\$ 1.45$ bids was randomly selected for rejection.

It should be noted that five auctions in addition to the trial auction were run in the first two experiments, ID and IC. Since the bid frequencies, the lowest accepted bid, and seller total revenue appear not to have stabilized, the number of auctions was increased to eight in experiments IIID and IIIC and to ten in experiments IVD and VC. Actually the question of equilibrium over time is a moot one. In a real market, conditions are not likely to remain constant long enough to achieve a static equilibrium. On the other hand, the participants in

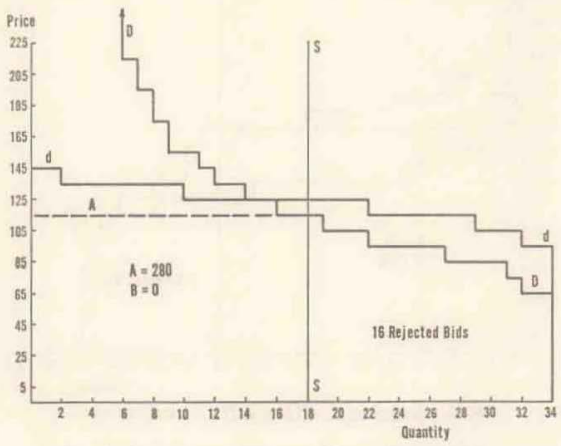

Frg. 4.-Experiments IV $D$ and VC, auction period 1

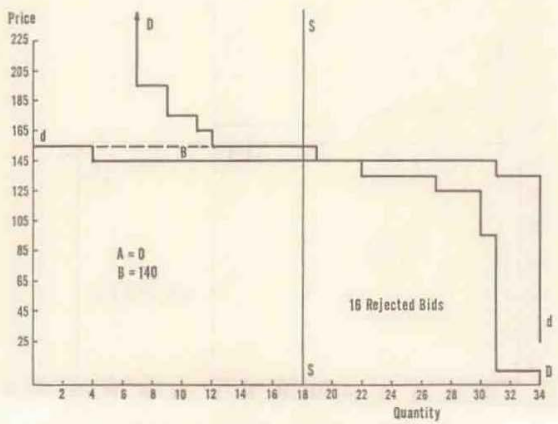

FIG, 5.-Experiments IVD and VC, auction period 10 
real markets are more experienced than subjects in laboratory experimental markets, and the behavior of the latter may be more comparable to that of the former only after several trials of learning experience.

The sample demand curves generated by the bid arrays in the first and last auction periods of experiments III $D$, IIIC, IVD, and VC are provided in Figures $2-5$. These charts convey some idea of the variation in the demand curves is the ratio of the variance of bids tendered under $C$ to those tendered under $D$. Only two of the twenty-three compared variances fail to be significantly different in the predicted direction at a probability levels of less than .001 . In the experiment $\mathrm{VC}$, the bid variance in every period was several thousand times as large as in IVD. In IVD and VC nearly half of the bids were rejected in each auction, putting the maximum pressure (relative to the other experiments) on subjects

TABLE 5

F-RATIO TEST OF $\mathrm{H}_{1}$ AND $\mathrm{H}_{1}^{\prime}$ $V\left(B_{c}\right)>V\left(B_{b}^{t}\right)$

\begin{tabular}{|c|c|c|c|c|c|c|c|c|c|c|c|c|}
\hline \multicolumn{3}{|c|}{$F$-RATto $=V\left(B_{C}^{t}\right) / V\left(B_{D}\right)$} & \multicolumn{10}{|c|}{ Aucrios Pertod } \\
\hline \multirow{2}{*}{$\begin{array}{c}\text { Paired } \\
\text { Experiments" }\end{array}$} & \multicolumn{2}{|c|}{$\begin{array}{l}\text { Degrees of } \\
\text { Freedom }\end{array}$} & \multirow{2}{*}{1} & \multirow{2}{*}{2} & \multirow{2}{*}{3} & \multirow{2}{*}{4} & \multirow{2}{*}{5} & \multirow{2}{*}{6} & \multirow{2}{*}{7} & \multirow{2}{*}{8} & \multirow{2}{*}{9} & \multirow{2}{*}{10} \\
\hline & fe & $f_{D}$ & & & & & & & & & & \\
\hline 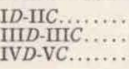 & $\begin{array}{l}29 \\
25 \\
31\end{array}$ & $\begin{array}{l}29 \\
25 \\
31\end{array}$ & $\begin{array}{l}4.3 \\
2.3^{* * *} \\
7,582\end{array}$ & $\begin{array}{l}9.5 \\
1.5^{*} \\
b\end{array}$ & $\begin{array}{c}15.3 \\
9.8 \\
b\end{array}$ & $\begin{array}{l}9.4 \\
9.8 \\
\mathrm{~b}\end{array}$ & $\begin{array}{r}25.4 \\
6.6 \\
b\end{array}$ & 5.7 & 5.2 & 5.3 & b & 28,500 \\
\hline
\end{tabular}

- In order of predicted increasing level of bids.

b All these $F$ 's are very large.

* Significant at $a=.10$.

$*$ Significant at $a=.025$. All other $P$-values significant at $a<.001$.

as between the two treatment conditions in different experimental groups. Generally, demand $d d$ (under discrimination) tended to rise and flatten relative to the price axis in successive auction periods. $D D$ (under competitive rules) tended to rise but not necessarily flatten, expecially in group $\mathrm{VC}$, in successive auctions.

A comparison of the distributions of bids under the $C$ and $D$ conditions for corresponding auction periods (Tables 3 and 4) leaves little doubt that the variance of bids is much higher under $C$ than $D$. The results of an $F$-test of $\mathrm{H}_{1}$ (and $\left.\mathrm{H}_{1}^{\prime}\right)$ is shown in Table 5. Each $F$ entry to bid high if they hoped to tender successful bids. However, much of this extreme variation may be attributable to the effect of a single subject in VC who entered two bids of over $\$ 100.00$ in the trial auction and in most of the auctions thereafter. This seems to have induced subsequent bids (up to nine) at very high levels by subjects seeing that (1) very high bids guaranteed success and (2) that enough other subjects entered cautious low bids to yield reasonably low purchase prices. By the fifth auction three subjects were entering bids at $\$ 0.05$ or 0 (see Appendix III), apparently to be certain of limiting their losses to a 
single bid in the event that the number of exorbitant bids should exceed the eighteen-unit offering. Many of the very high and very low bids are perhaps therefore attributable to the high bids submitted, and then advertised in the subsequent announcement, by a single subject. Hence, the group variance of bids under $C$ may vary sharply in different groups depending upon whether a group contains a subject willing to bid almost without limit to be sure of success. Such a bid is analogous to orders to "buy at market" on the organized stock exchanges. An order "buy at market" those appearing on its left in the order sequence. The test statistic $P$ is formed by taking each bid tendered by a $D$ group, starting with the lowest and counting the number of bids in the corresponding $C$ group that are greater. If for the $i$ th bid in a $D$ group there are $N_{i}$ larger bids in the parallel $C$ group, then

$$
P=\sum_{i} N_{i} .
$$

As the sample sizes increase, the distribution of $P$ converges rapidly to the normal. ${ }^{7}$

TABLE 6

JONCKHEERE TEST OF $\mathrm{H}_{2}$ AND $\mathrm{H}_{2}^{\prime}$

$$
B_{c}^{\prime}>B_{b}^{\prime}
$$

\begin{tabular}{|c|c|c|c|c|c|c|c|c|c|c|c|}
\hline \multicolumn{2}{|c|}{ z, Usit Norkal Devite } & \multicolumn{10}{|c|}{ Aucrios Pertod } \\
\hline $\begin{array}{c}\text { Paired } \\
\text { Experiments: }\end{array}$ & $\begin{array}{l}\text { No. of } \\
\text { Rejected } \\
\text { Buds }\end{array}$ & 1 & 2 & 3 & 4 & 5 & 6 & 7 & 8 & 9 & 10 \\
\hline $\begin{array}{l}\mathrm{II} D-\mathrm{II} C \ldots \ldots \ldots \\
\mathrm{I} D-\mathrm{II} C \\
\mathrm{IV} D-\mathrm{V} C \ldots \ldots \ldots \ldots\end{array}$ & $\begin{array}{r}8 \\
12 \\
16\end{array}$ & $\begin{array}{r}3.3 \\
3.6 \\
-1.0\end{array}$ & $\begin{array}{r}6.0 \\
3.9 \\
-0.7\end{array}$ & $\begin{array}{l}6.1 \\
4.3 \\
0.5\end{array}$ & $\begin{array}{l}4.5 \\
4.1 \\
1.4\end{array}$ & $\begin{array}{l}4.6 \\
4.0 \\
1.4\end{array}$ & $\begin{array}{l}2.8 \\
0.4\end{array}$ & $\begin{array}{l}4.5 \\
0.0\end{array}$ & $\begin{array}{l}3.8 \\
0.0\end{array}$ & 01 & $\dddot{\cdots} 6$ \\
\hline
\end{tabular}

- In order of predicted increasing level of bids. Entries in first two rows signilicant in predicted direction at a $<.001$. Entries in bottom row not significant in predicted direction.

placed with a stock broker instructs him to obtain title to the security on whatever terms are required. There is no upper limit to the purchase price.

Since $\mathrm{H}_{1}$ is very strongly confirmed it is clear that the testing of $\mathrm{H}_{2}$ and $\mathrm{H}_{2}^{\prime}$ cannot be based upon the assumption that the $C$ and $D$ populations of bids have a common variance. Therefore, instead of a $t$-test on bid means, our fundamental hypothesis, $\mathrm{H}_{2}$, will be tested by the Jonckheere procedure, ${ }^{6}$ which is a non-parametric (rank-order) test of the hypothesis that $k$ random variables have been ordered a priori so that each is stochastically larger than
Table 6 contains the values of the unit normal deviate, $Z$, computed for each auction period, on the a priori hypothesis that bids under condition $C$ would have higher ranks than those under $D$. In the first two sets of paired groups, corresponding to eight and twelve rejected bids, the $Z$ values are significant at $a<.001 . \mathrm{H}_{2}$ and $\mathrm{H}_{2}^{\prime}$ are

-A. R. Jonckheere, "A Test of Significance for the Relation between $m$ Rankings and $k$ Ranked Categories," British Journal of Slatistical Psychology, VII (November, 1954), 93-100, and idem, "A Distribution-Free $k$-Sample Test against Ordered Alternatives," Biomelriha, XII (June, 1954), 13345.

"Jonckheere, "A Distribution-Free $k$-Sample Test against Ordered Alternatives," p. 140. 
confirmed under these conditions. However, in the third pair of experiments, with sixteen rejected bids, $\mathrm{H}_{2}$ is not confirmed. The $Z$ values are small, and even negative in the first two auctions. Negative $Z$ here means that the bids under $C$ tend to be lower in rank than under $D$ the reverse of the order predicted by $\mathrm{H}_{2}$. These results suggest that we can expect bids under the $C$ treatment to exceed those under $D$ when the proportion of rejected bids is small or moderate. But this ordering relationship is reversed when the proportion of rejected bids approaches half the number of bids tendered.

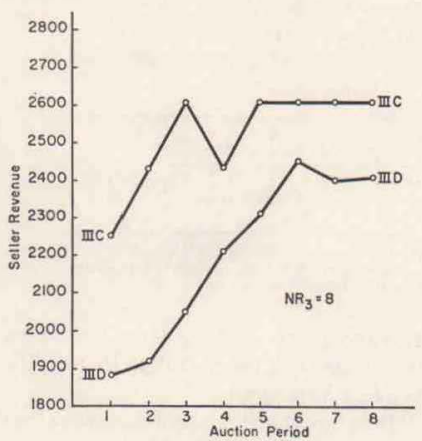

Fig. 6.-Seller revenue by auction period; test of $\mathrm{H}_{3}^{\prime}, R_{c}^{i}>R_{D}^{t}$.

Data relevant to the testing of $\mathrm{H}_{3}$ and $\mathrm{H}_{3}^{\prime}$ are contained in Figures 6,7 , and 8 , showing the total revenue accruing to a monopolistic seller, in each auction period, under the $C$ and $D$ conditions. $\mathrm{H}_{3}$ is supported by every observation in the experimental groups in which twelve bids were rejected (Fig. 7). However, $\mathrm{H}_{3}$ is supported only in the tenth auction, where sixteen bids are rejected in each auction period (Fig. 8). $\mathrm{H}_{3}^{\prime}$ is also supported by every observation (Fig. 6).

The results of Jonckheere tests of $\mathrm{H}_{4}$ and $\mathrm{H}_{5}$ are shown in Table 7. As suggested in our discussion of these hy-

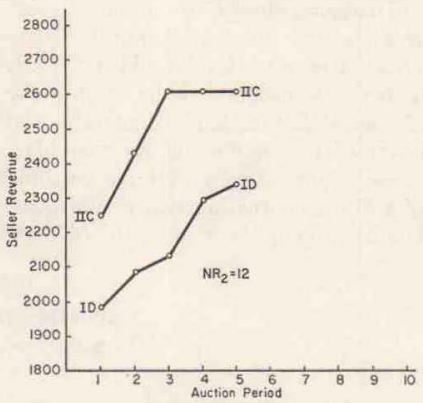

FIG. 7.-Seller revenue by auction period; test of $\mathrm{H}_{3}, R_{c}^{t}>R_{b}^{i}$.

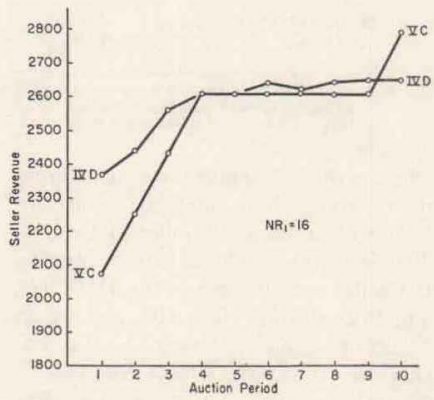

Fig. 8.-Seller revenue by auction period; test of $\mathrm{H}_{3}, R_{c}^{i}>R_{p}$.

potheses, the ordering relation $B_{D}^{t}$ (16) $>B_{D}^{t} \quad(12)>B_{D}^{t}$ (8) holds for discrimination, but the ordering $B_{C}^{t}$ $(16)>B_{C}^{t}$ (12) for competition is not confirmed. It is suspected that, under condition $D$, increasing the number of rejected bids beyond sixteen would not 
significantly increase the level of bids tendered, but this was not tested. (In Fig. 5 it is seen that the discrimination bids are crowding the mean, $\$ 1.55$, of the resale-price-density function.)

Therefore, under condition $C$, increasing the number of rejected bids does not raise the level of bids tendered. This simply means that the effect of the $C$ condition completely dominates the effect of the number of rejected bids. These results suggest that the outcome of a discrimination auction may depend crucially upon the number of bidders, the resale-price density. Since it has often been assumed or claimed that the stakes involved in laboratory experiments are small enough to approximate subject utility with a linear function, these theorems provide us with a test of this assumption. Examination of the data in Appendix III reveals that in the $D$ auctions only three subjects approached consistency in tendering equal bids: number 7 in IIID, 17 and 28 in IVD. In the $C$ auctions only two subjects tendered both bids at \$1.55: number 4 in IIC and 9 in IIIC. Five out of

\section{TABLE 7}

JONCKHEERE TEST OF $\mathrm{H}_{6}$ AND $\mathrm{H}_{5}$ $B_{b}^{b}(16)>B_{b}(12)>B_{b}(8), B_{b}^{b}(16)>B_{b}(12)$

\begin{tabular}{|c|c|c|c|c|c|}
\hline \multirow{2}{*}{$\begin{array}{l}Z \text {, Untr Nonkal Devicte } \\
\text { Compared Experiments }{ }^{n} . .\end{array}$} & \multicolumn{5}{|c|}{ Aucrion Period } \\
\hline & 1 & 2 & 3 & 4 & 5 \\
\hline $\begin{array}{l}\mathrm{H}_{4}: \mathrm{II} D-\mathrm{I} D-\mathrm{IV} D \ldots \ldots \ldots \\
\mathrm{H}_{5}: \mathrm{IC} C-\mathrm{V} C \ldots \ldots \ldots \ldots \ldots\end{array}$ & $\begin{array}{r}6.1 \\
-1.3^{b}\end{array}$ & $\begin{aligned} & 5.4 \\
- & 0.8^{b}\end{aligned}$ & $\begin{aligned} & 5.9 \\
- & 0.5^{b}\end{aligned}$ & $\begin{array}{l}5.0 \\
0.6\end{array}$ & $\begin{array}{r}3.6 \\
-0.1^{b}\end{array}$ \\
\hline
\end{tabular}

- In order of (1) increasing proportion of rejected bids and (2) predicted incressing level of bids.

b Negative values indicate that level of bids decreases as proportion of rejected bids increcses in $C$ treatment, contrary to prediction. All other 2 values are significant at a $<.001$ in the predicted direction.

whereas the outcome of the same offering under competition may be relatively independent of the number of bidders. This is further confirmed by comparing the seller-revenue curves for IIID, ID, and IVD and for IIIC, IIC, and VC in Figures 6,7 , and 8 . Under the $D$ condition we have $R_{D}^{t} \quad(16)>R_{D}^{t} \quad(12)>$ $R_{D}^{t}$ (8) for all auction periods. But under $C$, seller revenue is not unambiguousl $y$ larger the greater the number of rejected bids.

In Appendix I it is shown that an expected-profit maximizer (utility linear in money) would submit bids $p_{1}^{*}=$ $p_{2}^{*}<\bar{P}$ in a $D$ auction, and $p_{1}^{* *}=$ $p_{2}^{* *}=\bar{P}$ in a $C$ auction, where $\bar{P}(=$ $\$ 1.55$ in the experiments) is the mean of seventy-seven subjects tendered bids consistent with the postulate that utility is linear in money!

In terms of utility theory, these rather negative results could have any of several interpretations: (1) Subjects may tend to be expected-utility maximizers, where utility is linear in money, but with "noise" in their decision behavior or perceived utilities. (2) Subjects may tend to be expected-utility maximizers, but utility is nonlinear in money. (3) Subjects may tend to be expected-utility maximizers but with other variables, besides money, in the utility function. One obvious such variable is bid variety-it may be boring, tedious, or just. "uninteresting" to enter the same two bids auc- 
tion after auction. Some utility may therefore be derived from bid variety, and the lower the cash rewards the greater the relative strength of the urge to diversify. ${ }^{8}$ A test for such effects might be obtained by replication of the above experiments, with double the cash rewards, as a means of reducing the relative importance of bid variety in determining bid behavior.

\section{SUMMARY AND DISCUSSION}

This paper has initiated an experimental investigation of the effect of discrimination, competition, and the relative number of rejected bids on the level of bids tendered by subjects and the receipts of a monopolistic seller. The experimental paradigm is one in which subjects tender bids for an abstract commodity offered inelastically at a stated quantity. Purchase price to the individual is determined by his bid (if it is accepted) in the discriminative auction. It is determined by the lowest of all the accepted bids in the competitive auction. The abstract commodity is then sold at a price determined by a rectangularmass function. The essence of the decision task is to determine at what levels to tender two bids, with knowledge only of the results of the previous auctions (the high and low accepted bids) and of the rectangular distribution of resale price.

The results of six experiments lend tentative support to the following conclusions:

1. The variance of competitive bids is consistently greater than the variance

8 Sidney Siegel ("Decision-Making and Learning under Varying Conditions of Reinforcement," $A n$ nals of the New York Academy of Science, LXXXIX [January 28, 1961], 766-83) has employed a similar utility interpretation of differential behavior, under various reward conditions, in the binary-choice probability experiment. of discriminative bids. This discrepancy in bid variance tends to widen as the proportion of rejected bids increases.

2. For proportions of rejected bids that are low or moderate, competitive bids tend to stochastically dominate discriminative bids, that is, the probability of any bid $Y$ or less being received tends to be greater for the discriminative auction than for the competitive auction. The proposition fails for a high proportion of rejected bids, where "high" seems to be in the neighborhood of 50 per cent.

3 . The total receipts of a monopolistic seller are greater in a competitive auction than in a discriminative auction when the proportion of rejected bids is low or moderate. The proposition fails when there is a high proportion of rejected bids.

4. Discriminative auctions with a high proportion of rejected bids tend to stochastically dominate discriminative auctions with a lower proportion of rejected bids. The proposition does not hold in competitive auctions.

5. The total receipts of a monopolistic seller are greater, the greater the proportion of rejected bids in a discriminative auction. The proposition does not hold in competitive auctions.

6 . The bids of only five out of seventyseven subjects can be considered reasonably consistent with the postulate of a linear utility for money. However, the bids of the remaining seventy-two subjects do not necessarily imply utility functions that are non-linear in money if bid diversity itself is an argument of the utility function.

This study does not claim to be definitive. Only the surface is scratched. For given values of the treatment variablesmarket organization and proportion of rejected bids - the variability due to different subject groups has not been 
determined: some of the experiments should be replicated with different subjects to see if our results are confirmed. The constraint that no more than two bids are to be submitted by each subject is arbitrary and should be relaxed in later studies. The interesting set of experiments in which the number of bids to be submitted is also a decision variable are yet to be performed. In our experiments several subjects entered at least one of their two bids at levels so low that it was almost sure not to be accepted. Presumably such subjects would not have tendered additional bids, or at least not at effective levels. However, other subjects consistently risked two high bids and no doubt would have been tempted to tender additional high bids if given the opportunity. The result might render all auctions relatively independent of the number of bidders, with the number of bids submitted per subject varying inversely with the num- ber of subjects for a given quantity offering.

It would be of interest to develop a more specific experimental simulation of the Treasury auction, with subjects permitted to enter either "competitive" or "non-competitive" bids in the $D$ auction. Instead of a rectangular mass for resale price, samplings could be made from the actual historical frequency distribution $f\left(P_{D}-P_{B}\right)$, where $P_{D}$ is price in the existing-asset market at the time of delivery of new bills and $P_{B}$ is price in the existing-asset market at the time bids are tendered. In this paradigm, the subjects would be given $P_{B}$ (since such information is available to bidders in the bill market), as well as the quantity offering, at the beginning of each auction.

These are but a few of many possible variations on the present experiments that could sharpen or broaden the conclusions.

\section{APPENDIX I}

\section{BIDDING THEORY}

In this Appendix we develop static expected-utility models of individual decision behavior in discriminative and competitive auction markets. In the first model, Section A, we assume that the individual buyer has a fixed resale or limit price above which he will not bid for a unit of the commodity. This case provides the theory for the illustration in Figure 1 and, under the simplest set of assumptions, gives some analytical foundation for the intuitive conjecture that an individual may bid lower in a discriminative than in a competitive auction. This first model would apply in a situation in which the individual bidders had fixed limit prices above which they would or could not bid for units of the commodity or had certain known prices at which they could resell units of the commodity.
The second model, B, provides a static theory of bidding behavior for subject behavior in the several experiments reported in this paper in which the subjects buy units of an abstract commodity for resale at a price whose frequency distribution is known. Thus, the value of the traded item (resale price) is uncertain at the time bids are submitted.

\section{A. LTMIT OR RESALE PRICE FIXED}

For a typical buyer we assume the following:

1. A utility function of money, $U(m)$, with $U(0)=0$.

2. A subjective density function $f(x)$ for the minimum successful bid, $x$, in a discriminative auction, and $g(x)$ in a competitive auction; that is, for the discriminative 
case, the cumulative distribution function $F(t)=\int_{0}^{t} f(x) d x$ is the subjective probability that the minimum successful bid in a particular auction will be $t$ or less.

3. Expected-utility-maximization bidding behavior.

In a price-discrimination auction, the payoff to an individual will be $\pi=P-p$, if $p \geq x$ (his bid is successful), and $\pi=0$, if $p<x$ (his bid is unsuccessful), where $P$ is the individual's limit or resale price and $p$ is his bid price for a single unit or fixed lot of the item. Therefore, given $U(m)$ and $f(x)$ for such an auction, a subject who is a von Neumann-Morgenstern-Savage, subjectiveexpected-utility maximizer, should $\underset{p}{\max }$ $E_{D}(U)$, where

$$
E_{D}(U)=\int_{0}^{p} U(P-p) f(x) d x,
$$

for an individual entering a single bid. $E_{D}(U)$ is maximum at $p^{*}$ if

$$
\begin{aligned}
\frac{\partial E_{D}}{\partial p} & =U\left(P-p^{*}\right) f\left(p^{*}\right) \\
& -U^{\prime}\left(P-p^{*}\right) F\left(p^{*}\right)=0 .
\end{aligned}
$$

For an interior maximum at $p^{*}$, one must also have

$$
\begin{aligned}
\frac{\partial^{2} E_{D}}{\partial p^{2}} & =U\left(P-p^{*}\right) f^{\prime}\left(p^{*}\right) \\
& -2 U^{\prime}\left(P-p^{*}\right) f\left(p^{*}\right) \\
& +U^{\prime \prime}\left(P-p^{*}\right) F\left(p^{*}\right)<0 .
\end{aligned}
$$

The inequality in (A2) can be taken as a postulate, or, if we assume diminishing marginal utility, $U^{\prime \prime}<0$, and a unimodal density $f(p)$, then the inequality necessarily holds for solutions $p^{*}$ above the mode, since in that region $f^{\prime}(p)<0$. Geometrically, the condition (A2) requires the function $U(P-p) f(p)$ to cut $U^{\prime}(P-p) F(p)$ from above at $p^{*}$. Hence, if $U^{\prime}(P-p)>0$, $F(p)>0$ (as seems reasonable), the solution $p^{*}<P$ will be at point $D$, as illustrated in Figure 9.

In a competitive auction, by contrast, since all bids are filled at the uniform market-clearing price, the payoff to an individ- ual for a successful bid is independent of his bid, namely, $\pi=P-x$, if $p \geq x$, and $\pi=$ 0 , if $p<x$. Expected utility in such an auction is therefore

$$
E_{c}(U)=\int_{0}^{p} U(P-x) g(x) d x
$$

for a single bid. We assume $g(x)$ to be different from $f(x)$, since the individual bidders will expect the minimum successful bid to be different, presumably lower, under dis-

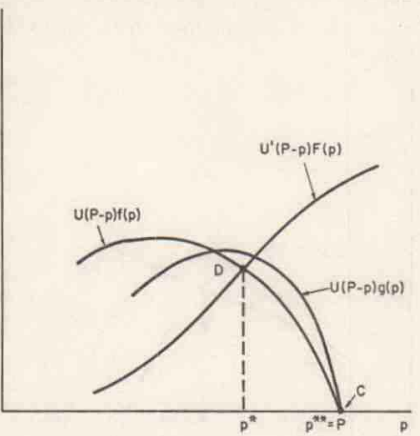

Fro. 9.-Optimal price bids under discrimination and competition.

crimination than under competition. That is, we would expect

$F(t)=\int_{0}^{t} f(x) d x \geq G(t)=\int_{0}^{t} g(x) d x$ for all $l$. For ${ }_{p}^{\max } E_{C}(U)$ at $p^{* *}$ we must have $\frac{\partial E_{C}}{\partial p}=U\left(P-p^{* *}\right) g\left(p^{* *}\right)=0$.

But if $U(P-p)>0$, and $f(p)>0$ on $0 \leq p<P$, and $U(P-p)=0$, when $p=$ $P$, the equality can only be satisfied at $p^{* *}=P$. That is, the theorem requires the individual to have a positive utility for money and to believe that there is at least some small probability that the minimum successful bid will be as high as his limit, $P$. Hence, as is intuitively 
obvious, in competitive auctions the expected-utility maximizer will bid his full limit or resale price, $P$. There is no penalty for winning the bid at a price above the market-clearing price, so the bidding problem reduces to the obvious one of maximizing the chance of success. This is accomplished by bidding the maximum possible, at $P$, as illustrated in Figure 9 at point $C$ (competition).

Hence, under the above assumptions, we conclude that a maximizer would bid lower under discrimination than under competition.

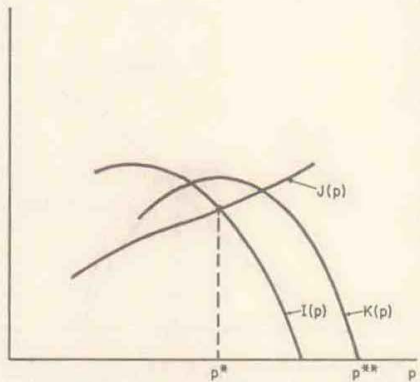

Frc. 10.-Optimal price bids under discrimination and competition.

\section{B. LIMIT OR RESALE PRICE UNCERTAIN}

Where the individual is to submit a single bid to buy a single unit or fixed lot of the item, we again assume a utility function $U(P-p)$ if the bid is successful, $U(0)=0$ otherwise. In addition, for the discriminative auction we assume a subjective joint density $f(x, P)$, where $x$ is the lowest accepted bid and $P$ the resale price. Similarly, for the competitive auction we assume a subjective joint density $g(x, P)$.

In the discriminative auction, expected utility is now

$E_{D}(U)=\int_{0}^{\infty} \int_{0}^{p} U(P-p) f(x, P) d x d P$.
Expected utility is maximum at $p^{*}$ if

$$
\frac{\partial E_{D}}{\partial p}=I\left(p^{*}\right)-J\left(p^{*}\right)=0
$$

and if

$$
\frac{\partial^{2} E_{D}}{\partial p^{2}}=I^{\prime}\left(p^{*}\right)-J^{\prime}\left(p^{*}\right)<0,
$$

where

$$
\begin{gathered}
I\left(p^{*}\right)=\int_{0}^{\infty} U\left(P-p^{*}\right) f\left(p^{*}, P\right) d P, \\
J\left(p^{*}\right)=\int_{0}^{\infty} \int_{0}^{p^{*}} U^{\prime}\left(P-p^{*}\right) \\
\quad \times f(x, P) d x d P .
\end{gathered}
$$

In a competitive auction, expected utility for the same bidder would be

$$
E_{c}(U)=\int_{0}^{\infty} \int_{0}^{p} U(P-x) g(x, P) d x d P .
$$

A maximum at $p^{* *}$ requires

$$
\frac{\partial E_{c}}{\partial p}=K\left(p^{* *}\right)=0,
$$

and

$$
\frac{\partial^{2} E_{C}}{\partial p^{2}}=K^{\prime}\left(p^{* *}\right)<0,
$$

where

$$
\begin{aligned}
& K\left(p^{* *}\right)=\int_{0}^{\infty} U\left(P-p^{* *}\right) \\
& \times g\left(p^{* *}, P\right) d P .
\end{aligned}
$$

The condition (B2) requires $I(p)$ to cut $J(p)$ from above at $p^{*}$, as shown in Figure 10. In order for $p^{* *}$ to exceed $p^{*}$ we see from Figure 10 that it is sufficient for $K(p)$ to lie above $I(p)-J(p)$ in the region above $p^{*}$. That we may have $p^{* *}>p^{*}$ is readily demonstrated. For example, consider the case in which utility is linear in money, $U(m) \equiv m$. Then (B1) can be written

$$
\begin{aligned}
& \int_{0}^{\infty}\left(P-p^{*}\right) f\left(p^{*}, P\right) d P \\
&-\int_{0}^{\infty} \int_{0}^{n^{*}} f(x, P) d x d P=0 .
\end{aligned}
$$


The second term is the cumulative marginalprobability function $F_{1}\left(p^{*}\right)$. Substituting $f\left(p^{*}, P\right)=f\left(P \mid p^{*}\right) f_{1}\left(p^{*}\right)$ we get

$f_{1}\left(p^{*}\right)\left[E_{f}\left(P \mid p^{*}\right)-p^{*}\right]=F_{1}\left(p^{*}\right)$.

Similarly, (B3) becomes

$$
g_{1}\left(p^{* *}\right)\left[E_{g}\left(P \mid p^{* *}\right)-p^{* *}\right]=0 .
$$

If we make the reasonable assumption that expected resale price in the discriminative auction cannot be greater than that in the competitive auction, that is,

$\bar{P}\left(p^{*}\right) \equiv E_{f}\left(P \mid p^{*}\right) \leq E_{v}\left(P \mid p^{* *}\right)$

$$
\equiv \bar{P}\left(p^{* *}\right) \text {, }
$$

then from $\left(B 1^{\prime}\right)$ and $\left(B 2^{\prime}\right)$

$$
\begin{aligned}
p^{*}=\bar{P}\left(p^{*}\right)-\frac{F_{1}\left(p^{*}\right)}{f_{1}\left(p^{*}\right)} & <\bar{P}\left(p^{*}\right) \\
& \leq \bar{P}\left(p^{* *}\right)=p^{* *} .
\end{aligned}
$$

This assumption surely holds in the experimental design in this paper, since the (rectangular) distribution of resale price is identical in the $C$ and $D$ auctions.

The conclusion is that a bidder submitting a single bid may (and we predict that he will) bid lower in a discriminative auction than in a corresponding competitive auction.

In our experiments the subjects are permitted to submit up to two bids each. We will therefore extend the above bidding theory to this case.

Let $0 \leq p_{1} \leq p_{2}$ be the two bids to be submitted, In the discriminative auction expected utility would be

$$
\begin{array}{r}
E^{D}(U)=\int_{0}^{\infty} \int_{0}^{p_{1}} U\left(2 P-p_{1}-p_{2}\right) \\
\quad \times f(x, P) d x d P \\
+\int_{0}^{\infty} \int_{p_{1}}^{p_{1}} U\left(P-p_{2}\right) f(x, P) d x d P,
\end{array}
$$

where the utility is $U\left(2 P-p_{1}-p_{2}\right)$ if both bids are successful, $U\left(P-p_{2}\right)$ if only the high bid is successful, and 0 if neither bid is accepted. A relative maximum occurs at $\left(p_{1}^{*}, p_{2}^{*}\right)$ if

$$
\begin{array}{r}
\frac{\partial E^{D}}{\partial p_{1}}=\int_{0}^{\infty} U\left(2 P-p_{1}^{*}-p_{2}^{*}\right) \\
\times f\left(p_{1}^{*}, P\right) d P \\
-\int_{0}^{\infty} \int_{0}^{p_{1}} U^{\prime}\left(2 P-p_{1}^{*}-p_{2}^{*}\right) \\
\times f(x, P) d x d P \\
-\int_{0}^{\infty} U\left(P-p_{2}^{*}\right) f\left(p_{1}^{*}, P\right) d P=0,
\end{array}
$$

$$
\begin{array}{r}
\frac{\partial E^{D}}{\partial p_{2}}=-\int_{0}^{\infty} \int_{0}^{p_{1}} U^{\prime}\left(2 P-p_{1}^{*}-p_{2}^{*}\right) \\
\times f(x, P) d x d P \\
+\int_{0}^{\infty} U\left(P-p_{2}^{*}\right) f\left(p_{2}^{*}, P\right) d P \\
-\int_{0}^{\infty} \int_{p_{1}}^{p_{1}^{*}} U^{\prime}\left(P-p_{2}^{*}\right) \\
\quad \times f(x, P) d x d P=0,
\end{array}
$$

and if

$$
\left|\begin{array}{ll}
E_{11}^{D} & E_{12}^{D} \\
E_{21}^{D} & E_{22}^{D}
\end{array}\right|>0, E_{11}^{D}<0 .
$$

If utility is linear in money, (B6) and (B7) can be written

$$
f_{1}\left(p_{1}^{*}\right)\left[E_{f}\left(P \mid p_{1}^{*}\right)-p_{1}^{*}\right]-F_{1}\left(p_{1}^{*}\right)=0,
$$

and

$$
f_{1}\left(p_{2}^{*}\right)\left[E_{f}\left(P \mid p_{2}^{*}\right)-p_{2}^{*}\right] F_{1}-\left(p_{2}^{*}\right)=0,
$$

where

$$
E_{f}\left(P \mid p_{i}^{*}\right)=\int_{0}^{\infty} P f\left(P \mid p_{i}^{*}\right) d P .
$$

Hence $\bar{P}\left(p_{1}^{*}\right)=\bar{P}\left(p_{2}^{*}\right)>p_{1}^{*}=p_{2}^{*}$. If utility is linear in money the theory implies that an individual submitting two bids should enter them at the same price and at a price below the mean of the subjective density of resale price. 

is

Expected utility in a competitive auction

$$
\begin{aligned}
E^{c}(U)=\int_{0}^{\infty} \int_{0}^{D_{1}} U(2 P-2 x) \\
\times g(x, P) d x d P \\
+\int_{0}^{\infty} \int_{D_{1}}^{p_{1}} U(P-x) \\
\times g(x, P) d x d P .
\end{aligned}
$$

Necessary conditions for a minimum can be written

$$
\begin{gathered}
\frac{\partial E^{c}}{\partial p_{1}}=\int_{0}^{\infty} U\left(2 P-2 p_{1}^{* *}\right) \\
\times g\left(p_{1}^{* *}, P\right) d P \\
-\int_{0}^{\infty} U\left(P-p_{1}^{* *}\right) \\
\times g\left(p_{1}^{* *}, P\right) d P=0
\end{gathered}
$$

and

$$
\begin{aligned}
\frac{\partial E^{c}}{\partial p_{2}}=\int_{0}^{\infty} U & \left(P-p_{2}^{* *}\right) \\
& \times g\left(p_{2}^{* *}, P\right) d P=0 .
\end{aligned}
$$

And for a relative maximum,

$$
\left|\begin{array}{ll}
E_{11}^{c} & E_{12}^{c} \\
E_{21}^{c} & E_{22}^{c}
\end{array}\right|>0, E_{11}^{c}<0 .
$$

If $U(m) \equiv m$, we can write (B9) and (B10) in the form

$$
\begin{aligned}
& \begin{aligned}
\frac{\partial E^{C}}{\partial p_{1}} & =\int_{0}^{\infty}\left(P-p_{1}^{* *}\right) g\left(P \mid p_{1}^{* *}\right) d P \\
& =g\left(p_{1}^{* *}\right)\left[E_{0}\left(P \mid p_{1}^{* *}\right)-p_{1}^{* *}\right]=0
\end{aligned} \\
& \text { and }
\end{aligned}
$$

$$
\begin{aligned}
\frac{\partial E^{c}}{\partial p_{2}}=\int_{0}^{\infty}\left(P-p_{2}^{* *}\right) & \\
& \times g\left(P \mid p_{2}^{* *}\right) g\left(p_{2}^{* *}\right) d P \\
= & g\left(p_{2}^{* *}\right)\left[E_{0}\left(P \mid p_{2}^{* *}\right)-p_{2}^{* *}\right]=0,
\end{aligned}
$$

and hence $\bar{P}\left(p_{1}^{* *}\right)=\tilde{P}\left(p_{2}^{* *}\right)=p_{1}^{* *}=p_{2}^{* *}$. If utility is linear in money, an individual submitting two bids in a competitive auction will enter both bids at the mean of the subjective density of resale price.

Thus, if expected resale price under competition is not less than its value under discrimination, $p_{1}^{*}=p_{2}^{*}<\bar{P}\left(p_{1}^{*}\right)=\bar{P}\left(p_{2}^{*}\right) \leq$ $\bar{P}\left(p_{1}^{* *}\right)=\bar{P}\left(p_{1}^{* *}\right)=p_{1}^{* *}=p_{2}^{* *}$, then, for utility that is linear in money, an individual's bids under discrimination will be lower than his bids under competition.

\section{APPENDIX II}

\section{INSTRUCTIONS}

EXPERIMENTS ID, IID, IVD

(DISCRTMINATIVE)

This is an experiment in the economics of market decision-making. The National Science Foundation has provided funds for conducting this research. The instructions are simple, and if you follow them carefully and make good decisions you may earn a considerable amount of money.

1. You will be given a starting capital credit balance of $\$ 1.00$. Any profit earned by you in the experiment will be added to this sum, and any losses incurred by you will be subtracted from this sum. Your net balance at the end of the experiment will be calculated and paid to you in real money.

2. This experiment will simulate a certain kind of market in which you will act as buyers in a sequence of trading periods. Each trading period begins with an announcement indicating the quantity of the fictitious commodity that is offered for sale.

3. In each period, your task is to attempt to buy units of the commodity by submitting written bids for it in competition with other buyers. Each unit that you are able to purchase is then resold by you at a price whose determination is explained below in paragraph 5. The procedure for determin- 
ing whether a bid for a unit is accepted, and the purchase price of that bid, will be explained in paragraph 6.

4. If a bid is not accepted your profit is zero. If a bid is accepted, you make a profit equal to the difference between your selling price and your purchase price. If this difference is negative, it represents a loss. That is, your profit for each unit is: profit $=$ (selling price) - (purchase price).

5. For all bids that are accepted, the resale price of each unit is determined by a random drawing (using a random-number table) from the following nine numbers: $\$ 1.15, \$ 1.25, \$ 1.35, \$ 1.45, \$ 1.55, \$ 1.65$, $\$ 1.75, \$ 1.85$, and $\$ 1.95$. Each of these prices is equally likely to be drawn in each market period. Since there are nine prices, this means that there is a $\frac{1}{9}$ chance that any one price will be drawn in any market period. For example; if $\$ 1.25$ is drawn in one period, this has no effect on the $\frac{1}{9}$ chance that $\$ 1.25$ will be drawn in any later market period.

You know the range within which the selling price will fall, $\$ 1.15-\$ 1.95$, and you know that each price in this range has a $\frac{1}{9}$ chance of occurring. But you do not know in advance, at the time you enter your bids to buy, what the exact selling price will be.

6 . Whether a bid is accepted, and at what price, is determined as follows: Suppose $X$ units are offered for sale at the beginning of a market period. Each bidder submits two written bids on cards supplied for this purpose. Each bid specifies a price for a single unit of the commodity. The bid prices must be in dollars and cents and end in the digit 5 , for example, $\$ 1.35, \$ 0.75$, $\$ 0.45$. These bids will be collected and then arrayed in descending order from the highest to the lowest. With $X$ units offered for sale, the first $X$ of these bids (starting with the highest) will be accepted, and the remaining bids will be rejected. In the case of ties at the lowest accepted bid price, random numbers will be used to determine which bids are to be accepted. The highest and lowest bids will then be announced. Each accepted bid will represent the purchase of one unit of the commodity at a purchase price equal to your bid price. Therefore, the higher your bid price the smaller is your potential profit on that bid if it is accepted. But the higher your bid the more likely it will be above the lowest accepted bid and thereby be accepted. You must weigh these considerations carefully in deciding upon each bid price to be submitted. A bid of zero is acceptable and is essentially equivalent to not entering a bid, or "standing pat."

7. Consider a numerical example. Suppose Jones submits two bids-one at $\$ 1.45$ and another at $\$ 0.65$. Suppose that the array of bids and the quantity offered are such that the highest accepted bid is $\$ 1.55$ and the lowest is $\$ 0.45$. Since both of Jones's bids were above $\$ 0.45$, they are accepted. He has purchased one unit at $\$ 1.45$ and another at $\$ 0.65$. Now assume that the result of the drawing to determine selling price yields a price of $\$ 1.35$. Then Jones has incurred a profit of $\$ 1.35-$ $\$ 1.45=-\$ 0.10$, a loss on one unit and a profit of $\$ 1.35-\$ 0.65=\$ 0.70$ on the second unit. His net profit is $\$ 0.60$ on the two bids.

As another example, suppose Jones submits bids at $\$ 0.85$ and $\$ 0.25$. Assume that the highest accepted bid is $\$ 1.25$ and the lowest is $\$ 0.55$. Then Jones's high bid was accepted while his low bid was not. That is, he has purchased one unit at $\$ 0.85$. Now let the result of the random drawing be a selling price of $\$ 1.65$. His profit on the single unit is $\$ 1.65-\$ 0.85=\$ 0.80$.

(Paragraphs 6 and 7 were supplemented with graphical illustrations like Figure 1, without the shaded area, but with the bids indicated in these paragraphs shown on the graphs.)

You are not to reveal your bids, or profits, nor are you to speak to any other subject while the experiment is in process.

Are there any questions?

EXPERIMENTS IIC, IIIC, vc (COMPETITIVE)

The instructions for the competitive treatments were the same as for the dis- 
criminative except for paragraphs 6 and 7 as follows:

6. Whether a bid is accepted, and at what price, is determined as follows: Suppose $X$ units are offered for sale at the beginning of a market period. Each bidder submits two written bids on cards supplied for this purpose. Each bid specifies a price for a single unit of the commodity. The bid prices must be in dollars and cents and end in the digit 5 , for example, $\$ 1.35, \$ 0.75$, and $\$ 0.45$. These bids will be collected and then arrayed in descending order from the highest to the lowest. With $X$ units offered for sale, the first $X$ of these bids (starting with the highest) will be accepted, and the remaining bids will be rejected. In the case of ties at the lowest accepted bid price, random numbers will be used to determine which bids are to be accepted. The highest and lowest bids will then be announced. Each accepted bid will represent the purchase of one unit of the commodity at a purchase price equal to the lowest accepled bid price, not your bid price. Therefore, your potential profit is not decreased if your bid is above the lowest accepted bid. The higher your bid the more likely it will be above the low bid and there- by be accepted. But your cost and potential profit are determined by the lowest accepted bid, not your bid. A bid of zero is acceptable and is essentially equivalent to not entering a bid, or "standing pat."

7. Consider a numerical example. Suppose Jones submits two bids-one at $\$ 1.45$ and another at $\$ 0.65$. Suppose that the array of bids and the quantity offered are such that the highest accepted bid is $\$ 1.55$ and the lowest is $\$ 0.45$. Since both Jones's bids were above $\$ 0.45$, they are accepted. $\mathrm{He}$ has purchased two units at $\$ 0.45$. Now assume that the result of the drawing to determine selling price yields a price of $\$ 1.35$. Then Jones has made a profit of $\$ 1.35-\$ 0.45=\$ 0.90$ on each unit, or a total of $\$ 1.80$ on the two bids.

As another example, suppose Jones submits bids of $\$ 0.85$ and $\$ 0.25$. Assume the highest accepted bid is $\$ 1.25$ and the lowest is $\$ 0.55$. Then Jones's high bid was accepted while his low bid was not. That is, he has purchased one unit at $\$ 0.55$. Now let the result of the random drawing be a selling price of $\$ 1.65$. His profit on the single unit is $\$ 1.65-\$ 0.55=\$ 1.10$. 


\section{APPENDIX III}

A. EXPERIMENTAL DATA, ID

\begin{tabular}{|c|c|c|c|c|c|c|c|c|c|c|c|c|}
\hline \multirow{2}{*}{$\begin{array}{c}\text { SUBJECt } \\
\text { No. }\end{array}$} & \multicolumn{2}{|c|}{ Auction 0} & \multicolumn{2}{|c|}{ Auction 1} & \multicolumn{2}{|c|}{ Auction 2} & \multicolumn{2}{|c|}{ Auction 3} & \multicolumn{2}{|c|}{ Auction 4} & \multicolumn{2}{|c|}{ Auction 5} \\
\hline & $p_{2}$ & $p_{1}$ & $p_{2}$ & $p r$ & $p 2$ & $p_{1}$ & $p_{2}$ & $p_{1}$ & $p_{2}$ & $p_{1}$ & $p_{2}$ & $p_{1}$ \\
\hline 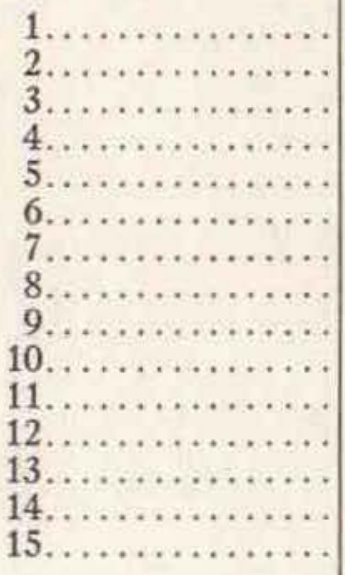 & $\begin{array}{l}\$ 1.35^{*} \\
1.15^{*} \\
0.65 \\
0.95^{*} \\
0.55^{*} \\
1.35^{*} \\
0.95^{*} \\
0.65 \\
1.05^{*} \\
1.35^{*} \\
1.15^{*} \\
1.05^{*} \\
1.05^{*} \\
1.25^{*} \\
1.45^{*}\end{array}$ & $\begin{array}{l}\$ 1.15^{*} \\
0.55 \\
0.45 \\
0.75 \\
0.45 \\
0.85^{*} \\
0.85^{*} \\
0.45 \\
0.75 \\
1.15^{*} \\
0.85^{*} \\
0.35 \\
0.85 \\
0.95^{*} \\
0.75\end{array}$ & $\begin{array}{l}\$ 1.25^{*} \\
1.25^{*} \\
0.85 \\
0.95 \\
1.05^{*} \\
1.25^{*} \\
0.95^{*} \\
1.15^{*} \\
1.25^{*} \\
1.05^{*} \\
1.05^{*} \\
1.05^{*} \\
1.05^{*} \\
1.15^{*} \\
1.35^{*}\end{array}$ & $\begin{array}{l}\$ 1.05^{*} \\
0.95 \\
0.75 \\
0.95 \\
0.95^{*} \\
0.95 \\
0.95^{*} \\
0.95 \\
0.95 \\
1.05^{*} \\
0.85 \\
0.95 \\
0.95 \\
0.95^{*} \\
0.75\end{array}$ & $\begin{array}{l}\$ 1.25^{*} \\
1.25^{*} \\
0.95 \\
1.05 \\
1.15^{*} \\
1.05 \\
1.05^{*} \\
1.15^{*} \\
1.05^{*} \\
1.15^{*} \\
1.15^{*} \\
1.25^{*} \\
1.15^{*} \\
1.15^{*} \\
1.25^{*}\end{array}$ & $\begin{array}{l}\$ 1.15^{*} \\
1.15^{*} \\
0.85 \\
0.95 \\
1.05^{*} \\
1.05 \\
1.05 \\
1.05 \\
1.05^{*} \\
1.05 \\
0.95 \\
1.25^{*} \\
1.05 \\
0.95 \\
1.15^{*}\end{array}$ & $\begin{array}{l}\$ 1.25^{*} \\
1.25^{*} \\
1.15^{*} \\
1.15 \\
1.15 \\
1.15 \\
1.15^{*} \\
1.15^{*} \\
1.15 \\
1.15 \\
1.15^{*} \\
1.25^{*} \\
1.15^{*} \\
1.15^{*} \\
1.35^{*}\end{array}$ & $\begin{array}{l}\$ 1.15^{*} \\
1.15^{*} \\
1.15^{*} \\
1.05 \\
1.15 \\
1.15 \\
1.15^{*} \\
1.15^{*} \\
1.05 \\
1.15 \\
1.05 \\
1.25^{*} \\
1.15^{*} \\
1.15 \\
1.15^{*}\end{array}$ & $\begin{array}{l}\$ 1.25^{*} \\
1.25^{*} \\
1.25^{*} \\
1.25^{*} \\
1.35^{*} \\
1.25^{*} \\
1.15 \\
1.15 \\
1.25^{*} \\
1.25^{*} \\
1.25^{*} \\
1.35^{*} \\
1.25^{*} \\
1.25^{*} \\
1.35^{*}\end{array}$ & $\begin{array}{l}\$ 1.25^{*} \\
1.25^{*} \\
1.15 \\
1.15 \\
1.25^{*} \\
1.15 \\
1.15 \\
1.05 \\
1.05 \\
1.25^{*} \\
1.15 \\
1.35^{*} \\
1.15 \\
1.15 \\
1.15\end{array}$ & $\begin{array}{l}\$ 1.35^{*} \\
1.25^{*} \\
1.35^{*} \\
1.25^{*} \\
1.35^{*} \\
1.35^{*} \\
1.25^{*} \\
1.25^{*} \\
1.15 \\
1.25 \\
1.35^{*} \\
1.35^{*} \\
1.25 \\
1.25 \\
1.35^{*}\end{array}$ & $\begin{array}{l}\$ 1.25^{*} \\
1.25^{*} \\
1.25^{*} \\
1.25^{*} \\
1.25 \\
1.35^{*} \\
1.25 \\
1.25 \\
1.05 \\
1.25 \\
1.25^{*} \\
1.35^{*} \\
1.25 \\
1.25 \\
1.25^{*}\end{array}$ \\
\hline $\begin{array}{l}\text { Highest accepted bid } \\
\text { Lowest accepted bid } \\
\text { Resale price....... }\end{array}$ & \multicolumn{2}{|c|}{$\begin{array}{r}\$ 1.45 \\
0.85 \\
1.75\end{array}$} & \multicolumn{2}{|c|}{$\begin{array}{r}\$ 1.35 \\
0.95 \\
1.15\end{array}$} & \multicolumn{2}{|c|}{$\begin{array}{r}\$ 1.25 \\
1.05 \\
1.95\end{array}$} & \multicolumn{2}{|c|}{$\begin{array}{r}\$ 1.35 \\
1.15 \\
1.35\end{array}$} & \multicolumn{2}{|c|}{$\begin{array}{r}\$ 1.35 \\
1.25 \\
1.95\end{array}$} & \multicolumn{2}{|c|}{$\begin{array}{r}\$ 1.35 \\
1.25 \\
1.45\end{array}$} \\
\hline
\end{tabular}

* Accept bids. 
B. EXPERIMENTAL DATA, IIC

\begin{tabular}{|c|c|c|c|c|c|c|c|c|c|c|c|c|}
\hline \multirow{2}{*}{$\begin{array}{c}\text { SUBjzcr } \\
\text { No. }\end{array}$} & \multicolumn{2}{|c|}{ Adcrion 0} & \multicolumn{2}{|c|}{ Avction 1} & \multicolumn{2}{|c|}{ Avcrios 2} & \multicolumn{2}{|c|}{ Aucrion 3} & \multicolumn{2}{|c|}{ Auction 4} & \multicolumn{2}{|c|}{ Aderion 5} \\
\hline & ps & $p_{1}$ & $\not 2$ & $p_{1}$ & $p 2$ & $p_{1}$ & $p 2$ & $p_{1}$ & $p$ & $p_{1}$ & $p 2$ & $p_{1}$ \\
\hline 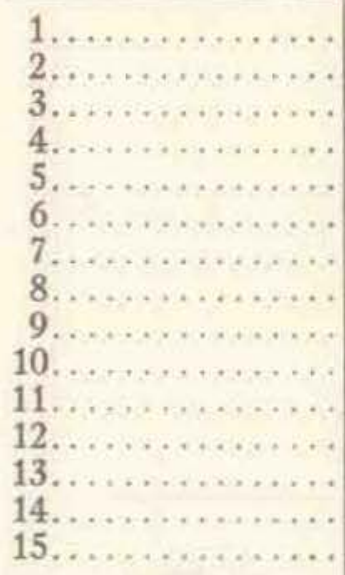 & $\begin{array}{l}\$ 1.45^{*} \\
1.75^{*} \\
1.75^{*} \\
1.55^{*} \\
1.15^{*} \\
1.75^{*} \\
1.05 \\
1.85^{*} \\
0.85 \\
1.65^{*} \\
0.65 \\
1.25^{*} \\
1.45^{*} \\
1.15^{*} \\
0.95\end{array}$ & $\begin{array}{l}\$ 0.75 \\
1.35^{*} \\
0.75 \\
1.45^{*} \\
0.85 \\
1.25^{*} \\
0.35 \\
1.75^{*} \\
0.05 \\
1.25^{*} \\
0.45 \\
0.55 \\
1.05^{*} \\
1.05^{*} \\
0.75\end{array}$ & $\begin{array}{l}\$ 1.55^{*} \\
1.85^{*} \\
1.45^{*} \\
1.55^{*} \\
1.35^{*} \\
1.75^{*} \\
1.75^{*} \\
1.45^{*} \\
1.15 \\
1.35^{*} \\
1.25^{*} \\
1.35^{*} \\
1.35^{*} \\
1.15 \\
1.75^{*}\end{array}$ & $\begin{array}{l}\$ 1.15 \\
1.35^{*} \\
0.45 \\
1.55^{*} \\
0.75 \\
1.25^{*} \\
1.05 \\
1.35^{*} \\
0.95 \\
1.25^{*} \\
1.15 \\
0.95 \\
1.15 \\
1.05 \\
1.25^{*}\end{array}$ & $\begin{array}{l}\$ 1.95^{*} \\
1.65^{*} \\
1.45^{*} \\
1.55^{*} \\
1.15^{*} \\
1.75^{*} \\
1.35^{*} \\
1.45^{*} \\
0.95 \\
1.75^{*} \\
1.55^{*} \\
1.65^{*} \\
1.45^{*} \\
1.35^{*} \\
1.65^{*}\end{array}$ & $\begin{array}{l}\$ 1.35^{*} \\
1.55^{*} \\
0.45^{*} \\
1.55^{*} \\
0.95 \\
1.35 \\
1.05 \\
1.35^{*} \\
0.65 \\
1.45^{*} \\
1.25 \\
1.25 \\
1.35 \\
1.15 \\
1.25\end{array}$ & $\begin{array}{l}\$ 1.95^{*} \\
1.65^{*} \\
1.45^{*} \\
1.55^{*} \\
1.45^{*} \\
1.75^{*} \\
1.35 \\
1.45^{*} \\
1.25 \\
1.55^{*} \\
1.55^{*} \\
1.65^{*} \\
1.55^{*} \\
1.25 \\
1.85^{*}\end{array}$ & $\begin{array}{l}\$ 1.45^{*} \\
1.45^{*} \\
1.15 \\
1.55^{*} \\
0.95 \\
1.75^{*} \\
1.15 \\
1.45^{*} \\
0.95 \\
1.35 \\
1.35 \\
1.35 \\
1.45^{*} \\
1.15 \\
1.25\end{array}$ & $\begin{array}{l}\$ 2.05^{*} \\
1.55^{*} \\
1.75^{*} \\
1.55^{*} \\
1.25 \\
1.45 \\
1.45^{*} \\
1.45^{*} \\
1.25 \\
1.75^{*} \\
1.55^{*} \\
1.65^{*} \\
1.55^{*} \\
1.85^{*} \\
1.55^{*}\end{array}$ & $\begin{array}{l}\$ 1.55^{*} \\
1.45^{*} \\
1.15 \\
1.55^{*} \\
0.95 \\
1.35 \\
1.15 \\
1.45^{*} \\
0.85 \\
1.35 \\
1.35 \\
1.55^{*} \\
1.55^{*} \\
1.35 \\
1.35\end{array}$ & $\begin{array}{l}\$ 1.95^{*} \\
1.65^{*} \\
1.75^{*} \\
1.55^{*} \\
1.75^{*} \\
1.75^{*} \\
1.45 \\
1.45 \\
1.35 \\
1.75^{*} \\
1.55^{*} \\
1.65^{*} \\
1.55^{*} \\
1.25 \\
1.95^{*}\end{array}$ & $\begin{array}{l}\$ 1.45^{*} \\
1.35 \\
1.55^{*} \\
0.45 \\
1.35 \\
1.65^{*} \\
1.15 \\
1.45 \\
1.15 \\
1.55^{*} \\
1.45^{*} \\
1.55^{*} \\
1.45^{*} \\
1.15 \\
1.35\end{array}$ \\
\hline $\begin{array}{l}\text { Highest accepted bid } \\
\text { Lowest accepted bid } \\
\text { Resale price....... }\end{array}$ & \multicolumn{2}{|c|}{$\begin{array}{r}\$ 1.85 \\
1.05 \\
1.75\end{array}$} & \multicolumn{2}{|c|}{$\begin{array}{r}\$ 1.85 \\
1.25 \\
1.15\end{array}$} & \multicolumn{2}{|c|}{$\begin{array}{r}\$ 1.95 \\
1.35 \\
1.95\end{array}$} & \multicolumn{2}{|c|}{$\begin{array}{r}\$ 1.95 \\
1.45 \\
1.35\end{array}$} & \multicolumn{2}{|c|}{$\begin{array}{r}\$ 2.05 \\
1.45 \\
1.95\end{array}$} & \multicolumn{2}{|c|}{$\begin{array}{r}\$ 1.95 \\
1.45 \\
1.45\end{array}$} \\
\hline
\end{tabular}

- Accept bids. 
C. Experimental Data, IIID

\begin{tabular}{|c|c|c|c|c|c|c|c|c|c|c|c|c|c|c|c|c|c|c|}
\hline \multirow{2}{*}{$\begin{array}{l}\text { SUBject } \\
\text { No. }\end{array}$} & \multicolumn{2}{|c|}{ Aucrion 0} & \multicolumn{2}{|c|}{ Auction 1} & \multicolumn{2}{|c|}{ Adction 2} & \multicolumn{2}{|c|}{ Auction 3} & \multicolumn{2}{|c|}{ Avcrios 4} & \multicolumn{2}{|c|}{ Avetron 5} & \multicolumn{2}{|c|}{ Auction 6} & \multicolumn{2}{|c|}{ Aucrion 7} & \multicolumn{2}{|c|}{ AdCTHON 8} \\
\hline & $p_{2}$ & $\not 1$ & $p_{2}$ & $p_{1}$ & $p_{2}$ & $p_{1}$ & $p_{2}$ & $p_{1}$ & $p_{2}$ & $p_{1}$ & $p_{2}$ & $p_{1}$ & $\not 2$ & $p_{1}$ & $\not 2$ & $p_{1}$ & $p_{2}$ & $p_{1}$ \\
\hline $\begin{array}{r}1 \ldots \ldots \ldots \\
2 \ldots \ldots \ldots \\
3 \ldots \ldots \ldots \\
4 \ldots \ldots \\
5 \ldots \ldots \\
6 \ldots \ldots \\
7 \ldots \ldots \\
8 \ldots \ldots \\
9 \ldots \ldots \ldots \\
10 \ldots \ldots \\
11 \ldots \ldots \ldots \\
12 \ldots \ldots \ldots \\
13 \ldots \ldots \ldots\end{array}$ & $\begin{array}{l}\$ 0.95^{*} \\
0.55 \\
0.55 \\
0.95^{*} \\
1.55^{*} \\
0.75^{*} \\
0.75^{*} \\
0.85^{*} \\
1.25^{*} \\
1.05^{*} \\
1.15^{*} \\
1.05^{*} \\
0.85^{*}\end{array}$ & $\begin{array}{l}\$ 0.55 \\
0.15 \\
0.25 \\
0.75^{*} \\
1.15^{*} \\
0.55 \\
0.65^{*} \\
0.65^{*} \\
0.55 \\
0.75^{*} \\
0.95^{*} \\
0.65^{*} \\
0.45\end{array}$ & $\begin{array}{l}\$ 0.95^{*} \\
0.95^{*} \\
1.45^{*} \\
0.95^{*} \\
1.45^{*} \\
0.85 \\
1.15^{*} \\
0.95^{*} \\
1.15^{*} \\
1.05^{*} \\
1.15^{*} \\
0.95^{*} \\
0.85\end{array}$ & $\begin{array}{l}\$ 0.85^{*} \\
0.65 \\
1.15^{*} \\
0.85 \\
0.95^{*} \\
0.75 \\
0.85 \\
0.75 \\
0.95^{*} \\
0.95^{*} \\
0.95^{*} \\
0.85^{*} \\
0.75\end{array}$ & \begin{tabular}{|l|}
$\$ 1.05^{*}$ \\
$1.05^{*}$ \\
$1.35^{*}$ \\
0.95 \\
$1.35^{*}$ \\
$0.95^{*}$ \\
$1.15^{*}$ \\
0.95 \\
$1.15^{*}$ \\
$1.05^{*}$ \\
$1.15^{*}$ \\
$1.05^{*}$ \\
$1.05^{*}$
\end{tabular} & $\begin{array}{l}\$ 1.05^{*} \\
0.65 \\
0.95^{*} \\
0.85 \\
0.95 \\
0.95 \\
0.95^{*} \\
0.85 \\
1.05^{*} \\
0.95^{*} \\
0.95^{*} \\
0.95^{*} \\
0.95\end{array}$ & $\begin{array}{l}\$ 1.15^{*} \\
1.05^{*} \\
1.25^{*} \\
1.05^{*} \\
1.25^{*} \\
1.15^{*} \\
1.15^{*} \\
1.15^{*} \\
1.15^{*} \\
1.05^{*} \\
1.15^{*} \\
1.15^{*} \\
1.05\end{array}$ & $\begin{array}{l}\$ 1.15^{*} \\
0.95 \\
1.05 \\
1.05 \\
1.15^{*} \\
1.05 \\
1.05 \\
1.05^{*} \\
1.15^{*} \\
1.05 \\
1.15^{*} \\
1.15^{*} \\
1.05\end{array}$ & \begin{tabular}{|c|}
$\$ 1.15^{*}$ \\
$1.15^{*}$ \\
$1.35^{*}$ \\
$1.35^{*}$ \\
$1.25^{*}$ \\
$1.25^{*}$ \\
$1.25^{*}$ \\
$1.25^{*}$ \\
$1.15^{*}$ \\
$1.25^{*}$ \\
$1.25^{*}$ \\
$1.25^{*}$ \\
$1.25^{*}$
\end{tabular} & $\begin{array}{l}\$ 1.15 \\
1.05 \\
1.15 \\
1.15 \\
1.25^{*} \\
1.15^{*} \\
1.15^{*} \\
1.15 \\
1.15 \\
1.25^{*} \\
1.15 \\
1.25^{*} \\
1.05\end{array}$ & $\begin{array}{c}\$ 1.25^{*} \\
1.25^{*} \\
1.35^{*} \\
1.35^{*} \\
1.35^{*} \\
1.25^{*} \\
1.25^{*} \\
1.25^{*} \\
1.25^{*} \\
1.25^{*} \\
1.35^{*} \\
1.35^{*} \\
1.35^{*}\end{array}$ & $\begin{array}{l}\$ 1.25^{*} \\
1.15 \\
1.15 \\
1.15 \\
1.25^{*} \\
1.25 \\
1.25 \\
1.25 \\
1.25^{*} \\
1.25 \\
1.25^{*} \\
1.25^{*} \\
1.05\end{array}$ & $\begin{array}{l}\$ 1.35 \\
1.25 \\
1.35^{*} \\
1.35^{*} \\
1.35^{*} \\
1.45^{*} \\
1.45^{*} \\
1.25 \\
1.35^{*} \\
1.35^{*} \\
1.35^{*} \\
1.35^{*} \\
1.35^{*}\end{array}$ & $\begin{array}{l}\$ 1.25 \\
1.25 \\
1.35^{*} \\
1.35^{*} \\
1.35^{*} \\
1.35^{*} \\
1.25 \\
1.25 \\
1.35^{*} \\
1.25 \\
1.35^{*} \\
1.35^{*} \\
1.25\end{array}$ & $\begin{array}{l}\$ 1.35^{*} \\
1.35^{*} \\
1.35^{*} \\
1.25^{*} \\
1.35^{*} \\
1.35^{*} \\
1.35^{*} \\
1.25 \\
1.25^{*} \\
1.35^{*} \\
1.35^{*} \\
1.35^{*} \\
1.35^{*}\end{array}$ & $\begin{array}{l}\$ 1.25 \\
1.25^{*} \\
1.25 \\
1.15 \\
1.35^{*} \\
1.25 \\
1.35^{*} \\
1.25 \\
1.25 \\
1.35^{*} \\
1.35^{*} \\
1.35^{*} \\
1.15\end{array}$ & \begin{tabular}{|l|}
$\$ 1.35^{*}$ \\
1.25 \\
$1.35^{*}$ \\
1.25 \\
$1.35^{*}$ \\
$1.35^{*}$ \\
$1.35^{*}$ \\
$1.35^{*}$ \\
1.25 \\
$1.35^{*}$ \\
$1.35^{*}$ \\
$1.35^{*}$ \\
$1.35^{*}$
\end{tabular} & $\begin{array}{l}\$ 1.25 \\
1.25 \\
1.25^{*} \\
1.25 \\
1.35^{*} \\
1.35^{*} \\
1.35^{*} \\
1.35^{*} \\
1.25 \\
1.25^{*} \\
1.35^{*} \\
1.35^{*} \\
1.15\end{array}$ \\
\hline $\begin{array}{c}\text { Highest ac- } \\
\text { cepted } \\
\text { bid...... } \\
\text { Lowest ac- } \\
\text { cepted } \\
\text { bid...... } \\
\text { Resale } \\
\text { price.... }\end{array}$ & \multicolumn{2}{|c|}{$\$ 1.55$} & \multicolumn{2}{|c|}{$\$ 1.45$} & \multicolumn{2}{|c|}{$\$ 1.35$} & \multicolumn{2}{|c|}{$\$ 1.25$} & \multicolumn{2}{|c|}{$\$ 1.35$} & \multicolumn{2}{|c|}{$\$ 1.35$} & \multicolumn{2}{|c|}{$\$ 1.45$} & \multicolumn{2}{|c|}{$\$ 1.35$} & \multicolumn{2}{|c|}{$\$ 1.35$} \\
\hline
\end{tabular}

* Accept bids. 
D. EXPERIMENTAL DATA, IIIC

\begin{tabular}{|c|c|c|c|c|c|c|c|c|c|c|c|c|c|c|c|c|}
\hline \multirow{2}{*}{$\begin{array}{c}\text { Subject } \\
\text { No. }\end{array}$} & \multicolumn{2}{|c|}{ Auction 1} & \multicolumn{2}{|c|}{ AUcrion 2} & \multicolumn{2}{|c|}{ Aucrion 3} & \multicolumn{2}{|c|}{ Auction 4} & \multicolumn{2}{|c|}{ Auctiox 5} & \multicolumn{2}{|c|}{ Aucrion 6} & \multicolumn{2}{|c|}{ Auction 7} & \multicolumn{2}{|c|}{ Aucrios 8} \\
\hline & $p_{2}$ & $p_{1}$ & $p 2$ & $\beta_{1}$ & $p_{2}$ & $p_{1}$ & $p_{2}$ & $p_{1}$ & $p_{2}$ & $p_{i}$ & $p_{2}$ & $p_{1}$ & $2 z$ & $p_{1}$ & $p_{2}$ & $p_{1}$ \\
\hline 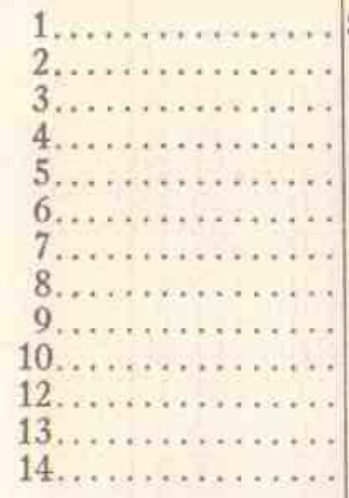 & $\begin{array}{l}\$ 1.25^{*} \\
1.55^{*} \\
1.35^{*} \\
1.35^{*} \\
1.35^{*} \\
1.25^{*} \\
1.45^{*} \\
1.95^{*} \\
1.65^{*} \\
1.45^{*} \\
0.95 \\
1.45^{*} \\
1.55^{*}\end{array}$ & $\begin{array}{l}\$ 1.25 \\
1.25^{*} \\
1.25^{*} \\
0.95 \\
1.25^{*} \\
1.15 \\
1.35^{*} \\
0.75^{*} \\
1.65^{*} \\
0.75 \\
0.85 \\
1.35^{*} \\
0.85\end{array}$ & $\begin{array}{l}\$ 1.35 \\
1.55^{*} \\
1.55^{*} \\
1.95^{*} \\
1.55^{*} \\
1.45^{*} \\
1.45^{*} \\
1.85^{*} \\
1.55^{*} \\
1.45^{*} \\
1.35^{*} \\
1.45^{*} \\
1.55^{*}\end{array}$ & $\begin{array}{l}\$ 1.25 \\
1.25 \\
1.35^{*} \\
1.25 \\
1.35^{*} \\
1.35 \\
1.45^{*} \\
1.25 \\
1.55^{*} \\
1.15 \\
1.35 \\
1.45^{*} \\
1.35^{*}\end{array}$ & $\begin{array}{l}\$ 1.35 \\
1.65^{*} \\
1.65^{*} \\
1.85^{*} \\
1.95^{*} \\
1.55^{*} \\
1.45^{*} \\
1.95^{*} \\
1.55^{*} \\
1.85^{*} \\
1.45^{*} \\
1.45^{*} \\
1.85^{*}\end{array}$ & $\begin{array}{l}\$ 1.25 \\
1.45 \\
1.35 \\
1.25 \\
1.75^{*} \\
1.45^{*} \\
1.45^{*} \\
1.95^{*} \\
1.55^{*} \\
1.35 \\
1.45 \\
1.45 \\
1.75^{*}\end{array}$ & $\begin{array}{l}\$ 1.35 \\
1.45^{*} \\
1.35 \\
1.35 \\
1.45^{*} \\
1.55^{*} \\
1.55^{*} \\
1.95^{*} \\
1.55^{*} \\
1.85^{*} \\
1.45^{*} \\
1.55^{*} \\
1.85^{*}\end{array}$ & $\begin{array}{l}\$ 1.25 \\
1.15 \\
1.25 \\
1.15 \\
1.45^{*} \\
1.55^{*} \\
1.35^{*} \\
1.95^{*} \\
1.55^{*} \\
1.25 \\
1.45^{*} \\
1.45^{*} \\
1.65^{*}\end{array}$ & \begin{tabular}{|l}
$\$ 1.35$ \\
$1.45^{*}$ \\
$1.85^{*}$ \\
1.35 \\
$1.45^{*}$ \\
$1.55^{*}$ \\
$1.55^{*}$ \\
$1.45^{*}$ \\
$1.55^{*}$ \\
$1.85^{*}$ \\
$1.45^{*}$ \\
$1.55^{*}$ \\
$1.85^{*}$
\end{tabular} & $\begin{array}{l}\$ 1.25 \\
1.25 \\
1.45^{*} \\
1.25 \\
1.45^{*} \\
1.45 \\
1.45 \\
1.45^{*} \\
1.55^{*} \\
1.35 \\
1.45^{*} \\
1.45^{*} \\
1.85^{*}\end{array}$ & $\begin{array}{l}\$ 1.35 \\
1.45^{*} \\
1.65^{*} \\
1.35 \\
1.65^{*} \\
1.55^{*} \\
1.55^{*} \\
1.35 \\
1.55^{*} \\
1.85^{*} \\
1.45^{*} \\
1.55^{*} \\
1.65^{*}\end{array}$ & $\begin{array}{l}\$ 1.25 \\
1.45^{*} \\
1.35 \\
1.25 \\
1.45^{*} \\
1.45^{*} \\
1.45^{*} \\
1.35 \\
1.55^{*} \\
1.45^{*} \\
1.45^{*} \\
1.45^{*} \\
1.25\end{array}$ & $\begin{array}{l}\$ 1.45^{*} \\
1.55^{*} \\
1.45^{*} \\
1.35 \\
1.45^{*} \\
1.55^{*} \\
1.55^{*} \\
1.85^{*} \\
1.55^{*} \\
1.85^{*} \\
1.45^{*} \\
1.55^{*} \\
1.55^{*}\end{array}$ & $\begin{array}{l}\$ 1.35 \\
1.45^{*} \\
1.45^{*} \\
1.35 \\
1.35 \\
1.45^{*} \\
1.45 \\
1.85^{*} \\
1.55^{*} \\
1.35 \\
1.45 \\
1.45^{*} \\
1.35\end{array}$ & $\begin{array}{l}\$ 1.45^{*} \\
1.55^{*} \\
1.45^{*} \\
1.35 \\
1.45^{*} \\
1.55^{*} \\
1.55^{*} \\
1.35 \\
1.55^{*} \\
1.85^{*} \\
1.45^{*} \\
1.55^{*} \\
1.85^{*}\end{array}$ & $\begin{array}{l}\$ 1.35 \\
1.45^{*} \\
1.35 \\
1.35 \\
1.45^{*} \\
1.45^{*} \\
1.35 \\
1.35 \\
1.55^{*} \\
1.45^{*} \\
1.45^{*} \\
1.45 \\
1.35\end{array}$ \\
\hline $\begin{array}{l}\text { Highest accepted bid } \\
\text { Lowest accepted bid } \\
\text { Resale price....... }\end{array}$ & \multicolumn{2}{|c|}{$\begin{array}{r}\$ 1.95 \\
1.25 \\
1.35\end{array}$} & \multicolumn{2}{|c|}{$\begin{array}{r}\$ 1.95 \\
1.35 \\
1.45\end{array}$} & \multicolumn{2}{|c|}{$\begin{array}{r}\$ 1.95 \\
1.45 \\
1.35\end{array}$} & \multicolumn{2}{|c|}{$\begin{array}{r}\$ 1.95 \\
1.35 \\
1.75\end{array}$} & \multicolumn{2}{|c|}{$\begin{array}{r}\$ 1.85 \\
1.45 \\
1.95\end{array}$} & \multicolumn{2}{|c|}{$\begin{array}{r}\$ 1.85 \\
1.45 \\
1.25\end{array}$} & \multicolumn{2}{|c|}{$\begin{array}{r}\$ 1.85 \\
1.45 \\
1.75\end{array}$} & \multicolumn{2}{|c|}{$\begin{array}{r}\$ 1.85 \\
1.45 \\
1.35\end{array}$} \\
\hline
\end{tabular}

* Accept bid. 
E. Experimental DATA, IVD

\begin{tabular}{|c|c|c|c|c|c|c|c|c|c|c|c|c|c|c|c|c|c|c|c|c|c|c|}
\hline \multirow{2}{*}{$\begin{array}{c}\text { SUBJECT } \\
\text { No. }\end{array}$} & \multicolumn{2}{|c|}{ Aucrion 0} & \multicolumn{2}{|c|}{ Auction 1} & \multicolumn{2}{|c|}{ Auction 2} & \multicolumn{2}{|c|}{ Aucrion 3} & \multicolumn{2}{|c|}{ Auctios 4} & \multicolumn{2}{|c|}{ Averion 5} & \multicolumn{2}{|c|}{ Auction 6} & \multicolumn{2}{|c|}{ Auctros 7} & \multicolumn{2}{|c|}{ Auction 8} & \multicolumn{2}{|c|}{ Averion 9} & \multicolumn{2}{|c|}{ Auction 10} \\
\hline & $p_{2}$ & $p_{1}$ & $p_{2}$ & $p_{1}$ & $p_{2}$ & $p_{1}$ & $p 2$ & $p_{1}$ & $p_{2}$ & $p_{1}$ & $p_{2}$ & $p_{1}$ & $p_{2}$ & $p_{1}$ & $p_{2}$ & $p_{1}$ & $p_{2}$ & $p_{1}$ & $p_{2}$ & $p_{1}$ & $p z$ & $p_{1}$ \\
\hline 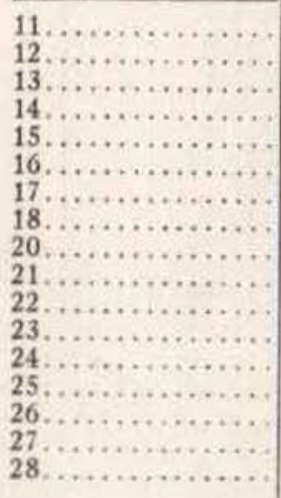 & \begin{tabular}{|c|}
$\$ 1.45^{*}$ \\
$1.25 *$ \\
$1.15^{*}$ \\
$1.25^{*}$ \\
$1.65^{*}$ \\
$1.45^{*}$ \\
0.95 \\
0.95 \\
1.05 \\
0.85 \\
$1.15^{*}$ \\
$1.25^{*}$ \\
$1.15^{*}$ \\
$1.25 *$ \\
0.95 \\
1.05 \\
$1.45^{*}$
\end{tabular} & $\begin{array}{l}\$ 1.25^{*} \\
0.85 \\
0.75 \\
1.55^{*} \\
1.75^{*} \\
0.75 \\
0.75 \\
1.35^{*} \\
0.65 \\
1.05 \\
0.75 \\
1.15 * \\
0.95 \\
1.35 * \\
0.95 \\
1.05 \\
1.35^{*}\end{array}$ & \begin{tabular}{|c|}
$\$ 1.45^{*}$ \\
1.25 \\
$1.35 *$ \\
$1.45 *$ \\
$1.25 *$ \\
1.15 \\
$1.35 *$ \\
$1.35 *$ \\
1.15 \\
$1.35 *$ \\
1.15 \\
$1.25 *$ \\
$1.35 *$ \\
$1.25 *$ \\
1.05 \\
1.25 \\
$1.35^{*}$
\end{tabular} & $\begin{array}{l}\$ 1.25^{*} \\
0.95 \\
1.25^{*} \\
1.25 \\
1.15 \\
1.05 \\
1.35^{*} \\
0.95 \\
1.25 \\
1.25^{*} \\
1.15 \\
1.25^{*} \\
1.15 \\
1.25^{*} \\
1.15 \\
1.05 \\
1.35^{*}\end{array}$ & $\begin{array}{l}\$ 1.45 * \\
1.25 \\
1.25 \\
1.35 * \\
1.35^{*} \\
1.15 \\
1.35 * \\
1.35 * \\
1.15 \\
1.35 * \\
1.15 \\
1.35 * \\
1.35 * \\
1.35 * \\
1.35 * \\
1.35 * \\
1.35 *\end{array}$ & $\begin{array}{l}\$ 1.25 \\
1.05 \\
0.95 \\
1.25 \\
1.35 * \\
1.25 \\
1.35 * \\
1.35^{*} \\
1.05 \\
1.25 \\
1.15 \\
1.25 \\
1.35^{*} \\
1.25 \\
1.35^{*} \\
1.25 \\
1.35^{*}\end{array}$ & $\begin{array}{l}\$ 1.45^{*} \\
1.45^{*} \\
1.25 \\
1.45^{*} \\
1.45^{*} \\
1.35 \\
1.45 * \\
1.45 * \\
1.45^{*} \\
1.35 * \\
1.35^{*} \\
1.45^{*} \\
1.45^{*} \\
1.35 \\
1.25 \\
1.35 \\
1.35^{*}\end{array}$ & $\begin{array}{l}\$ 1.25 \\
1.35 \\
1.35 \\
1.25 \\
1.45^{*} \\
1.25 \\
1.45^{*} \\
1.45^{*} \\
1.45^{*} \\
1.25 \\
1.25 \\
1.35^{*} \\
1.35 \\
1.15 \\
1.25 \\
1.15 \\
1.35^{*}\end{array}$ & \begin{tabular}{|c|}
$\$ 1.45 *$ \\
$1.45 *$ \\
$1.55 *$ \\
$1.45 *$ \\
$1.45 *$ \\
1.35 \\
$1.45 *$ \\
$1.45 *$ \\
1.35 \\
$1.35 *$ \\
$1.55 *$ \\
1.35 \\
$1.45 *$ \\
$1.45 *$ \\
$1.35 *$ \\
$1.45 *$ \\
1.35
\end{tabular} & $\begin{array}{l}\$ 1.35 \\
1.35 \\
1.15 \\
1.25 \\
1.45^{*} \\
1.35 \\
1.45^{*} \\
1.45^{*} \\
1.35 \\
1.25 \\
1.35 \\
1.35 \\
1.45^{*} \\
1.35 \\
1.35 \\
1.45 * \\
1.35\end{array}$ & \begin{tabular}{|c|}
$1.45^{*}$ \\
1.45 \\
$1.45^{*}$ \\
1.35 \\
$1.45^{*}$ \\
$1.45 *$ \\
$1.45 *$ \\
$1.45^{*}$ \\
$1.45^{*}$ \\
$1.45^{*}$ \\
$1.45^{*}$ \\
$1.45 *$ \\
$1.45^{*}$ \\
$1.45^{*}$ \\
1.25 \\
1.35 \\
$1.45^{*}$
\end{tabular} & $\begin{array}{l}\$ 1.35 \\
1.45 \\
1.25 \\
1.35 \\
1.45^{*} \\
1.35 \\
1.35 \\
1.45^{*} \\
1.35 \\
1.35 \\
1.45^{*} \\
1.35 \\
1.45^{*} \\
1.35 \\
1.25 \\
1.35 \\
1.45^{*}\end{array}$ & \begin{tabular}{|c|}
$\$ 1.45 *$ \\
$1.55^{*}$ \\
1.35 \\
1.35 \\
$1.45 *$ \\
$1.45^{*}$ \\
1.35 \\
$1.45^{*}$ \\
1.35 \\
$1.45^{*}$ \\
$1.55^{*}$ \\
$1.45^{*}$ \\
$1.45 *$ \\
$1.55^{*}$ \\
1.35 \\
$1.45 *$ \\
$1.45^{*}$
\end{tabular} & \begin{tabular}{|l|}
$\$ 1.35$ \\
$1.45 *$ \\
1.25 \\
1.35 \\
1.45 \\
$1.45^{*}$ \\
1.35 \\
$1.45^{*}$ \\
1.25 \\
1.35 \\
1.35 \\
1.35 \\
$1.45 *$ \\
1.45 \\
1.35 \\
$1.45 *$ \\
$1.45^{*}$
\end{tabular} & $\begin{array}{l}\$ 1.35 \\
1.45^{*} \\
1.25 \\
1.45 \\
1.45 * \\
1.45^{*} \\
1.45^{*} \\
1.45^{*} \\
1.15 \\
1.45 * \\
1.45^{*} \\
1.45 \\
1.45 \\
1.55 * \\
1.45^{*} \\
1.45^{*} \\
1.45^{*}\end{array}$ & $\begin{array}{l}\$ 1.45 \\
1.45^{*} \\
1.25 \\
1.35 \\
1.45 \\
1.45 * \\
1.45 * \\
1.45 * \\
1.35 \\
1.45 \\
1.45 \\
1.45 \\
1.35 \\
1.45 * \\
1.45^{*} \\
1.45 \\
1.45 *\end{array}$ & $\begin{array}{c}\$ 1.45^{*} \\
1.45 * \\
1.45^{*} \\
1.35 \\
1.45 * \\
1.45 * \\
1.55 * \\
1.45 * \\
1.35 \\
1.45 * \\
1.45 * \\
1.45 * \\
1.45 * \\
1.55 * \\
1.45 * \\
1.45 * \\
1.45\end{array}$ & $\begin{array}{l}\$ 1.45 \\
1.45 \\
1.25 \\
1.45 \\
1.45 \\
1.45 \\
1.55^{*} \\
1.45^{*} \\
1.35 \\
1.45 \\
1.45^{*} \\
1.45 \\
1.35 \\
1.45^{*} \\
1.45 \\
1.45 \\
1.45\end{array}$ & $\begin{array}{l}\$ 1.45^{*} \\
1.45 * \\
1.35 \\
1.45 * \\
1.55^{*} \\
1.45 \\
1.55 * \\
1.45^{*} \\
1.45^{*} \\
1.45^{*} \\
1.45^{*} \\
1.45 \\
1.45^{*} \\
1.45 \\
1.45 * \\
1.55^{*} \\
1.45^{*}\end{array}$ & \begin{tabular}{|l|l|}
$\$ 1.45^{*}$ \\
1.45 \\
1.25 \\
1.35 \\
1.45 \\
1.45 \\
$1.45 *$ \\
$1.45^{*}$ \\
1.35 \\
1.45 \\
1.45 \\
1.45 \\
$1.45 *$ \\
1.45 \\
1.45 \\
$1.55 *$ \\
1.45
\end{tabular} & \begin{tabular}{|l|}
$\$ 1.45^{*}$ \\
$1.45^{*}$ \\
$1.45^{*}$ \\
1.45 \\
$1.55^{*}$ \\
$1.45^{*}$ \\
$1.55^{*}$ \\
1.45 \\
$1.45^{*}$ \\
$1.45^{*}$ \\
$1.45^{*}$ \\
1.45 \\
$1.45^{*}$ \\
$1.45^{*}$ \\
$1.45^{*}$ \\
$1.55^{*}$ \\
1.45
\end{tabular} & $\begin{array}{l}\$ 1.45 \\
1.45^{*} \\
1.35 \\
1.35 \\
1.45 \\
1.45 * \\
1.45^{*} \\
1.45 \\
1.35 \\
1.45^{*} \\
1.45 \\
1.45 \\
1.45 \\
1.45 \\
1.45 \\
1.55 * \\
1.45\end{array}$ \\
\hline $\begin{array}{l}\text { Highest accepted bid } \\
\text { Lowest accepted bid } \\
\text { Resale price....... }\end{array}$ & \multicolumn{2}{|c|}{$\begin{array}{r}\$ 1.75 \\
1.15 \\
1.75\end{array}$} & \multicolumn{2}{|c|}{$\begin{array}{r}\$ 1.45 \\
1.25 \\
1.15\end{array}$} & \multicolumn{2}{|c|}{$\begin{array}{r}\$ 1.45 \\
1.35 \\
1.95\end{array}$} & \multicolumn{2}{|c|}{$\begin{array}{r}\$ 1.45 \\
1.35 \\
1.35\end{array}$} & \multicolumn{2}{|c|}{$\begin{array}{r}\$ 1.55 \\
1.35 \\
1.95\end{array}$} & \multicolumn{2}{|c|}{$\begin{array}{r}\$ 1.45 \\
1.45 \\
1.45\end{array}$} & \multicolumn{2}{|c|}{$\begin{array}{r}\$ 1.55 \\
1.45 \\
1.15\end{array}$} & \multicolumn{2}{|c|}{$\begin{array}{r}\$ 1.55 \\
1.45 \\
1.35\end{array}$} & \multicolumn{2}{|c|}{$\begin{array}{r}\$ 1.55 \\
1.45 \\
1.85\end{array}$} & \multicolumn{2}{|c|}{$\begin{array}{l}\$ 1.55 \\
1.45 \\
1.55\end{array}$} & \multicolumn{2}{|c|}{$\begin{array}{r}\$ 1.55 \\
1.45 \\
1.35\end{array}$} \\
\hline
\end{tabular}

* Accept bid. 
F. EXPERIMENTAL DATA, VC

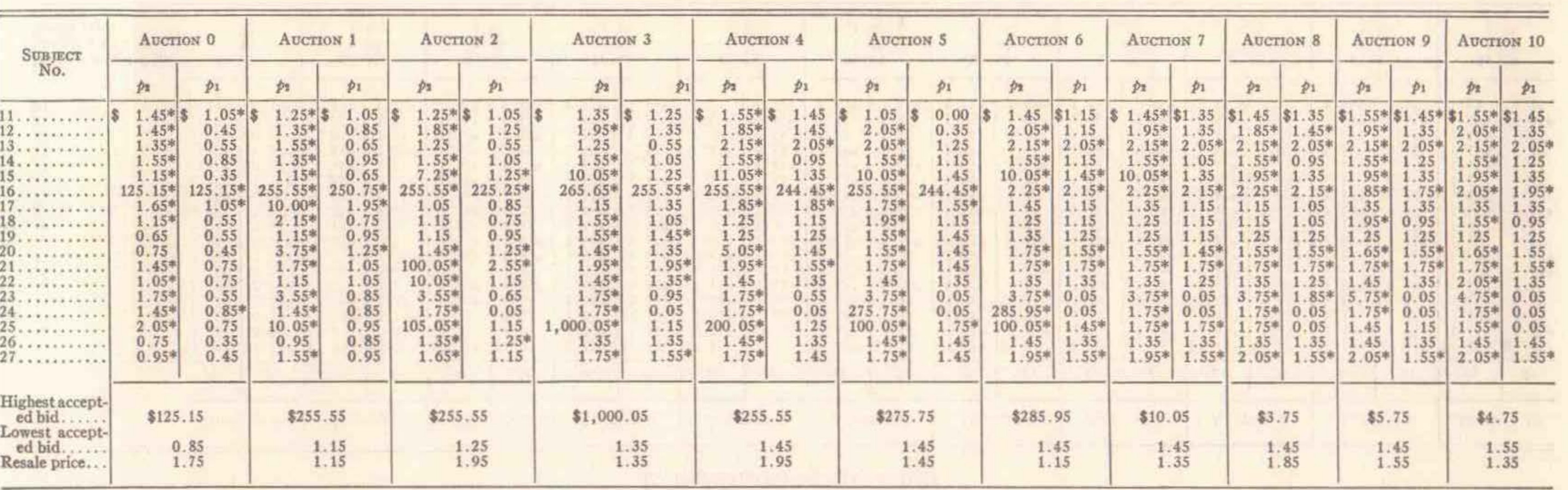

- Accepted bid. 
Copyright of Journal of Business is the property of University of Chicago Press and its content may not be copied or emailed to multiple sites or posted to a listserv without the copyright holder's express written permission. However, users may print, download, or email articles for individual use. 